\title{
Melitidae (Crustacea, Amphipoda) from anchihaline limestone caves in New Caledonia
}

\author{
Jan H. Stock* \& Thomas M. Iliffe** \\ *c/o Institute for Systematics and Population Biology, University of Amsterdam, P.O. Box 94766, \\ 1090 GT Amsterdam, The Netherlands; ${ }^{* *}$ Department of Marine Biology, Texas A \& M University at \\ Galveston, P.O. Box 1675, Galveston, Texas 77553, U.S.A.
}

Keywords: Cave amphipods, Melitidae, New Caledonia, Josephosella, Caledopisa, taxonomy

\begin{abstract}
Four new species of Melitidae (Amphipoda) are described from anchihaline limestone caves in New Caledonia. Three species are classified with Josephosella Ruffo, 1985 (J. microps n. sp., J. debilis n. sp., and J. proiecta n. sp.) and a new genus, Caledopi$s a$, is erected for the fourth species, $C$. levis $\mathrm{n}$. sp. The new genus is related to Victoriopisa Karaman \& Barnard, 1979.
\end{abstract}

\section{Résumé}

Quatre espèces nouvelles d'Amphipodes Melitidae sont décrites des eaux anchihalines de grottes calcaires de la Nouvelle Calédonie. Trois de ces espèces appartiennent au genre Josephosella Ruffo, 1985 (J. microps n. sp., J. debilis n. sp. et $J$. proiecta n. sp.), tandis qu'un genre nouveau, Caledopisa, est institué pour une quatrième espèce, $C$. levis n. sp. Ce genre nouveau est apparenté à Victoriopisa Karaman \& Barnard, 1979.

\section{Introduction}

A rich collection of amphipods was obtained in anchihaline limestone caves, with salinities between 0.5 and $15 \mathrm{ppt}$, in New Caledonia during fieldwork of the second author and S. Serbu in 1988. Most of the material consisted of members of the family Melitidae s. str. (= "Melitids" or "Melita-group" in Barnard \& Barnard, 1983: 376 and 662). The New Caledonian taxa show great resemblance to marine or brackish-water forms, and, though cavernicolous, all bear eyes, be it reduced usually. This appears to suggest that they are of fairly recent descent, from marine ancestors, like so many stygobiont amphipods in the tropics.
Two genera are represented: Josephosella, a hitherto monospecific genus recently described from the marine interstitial of the Andaman Islands by Ruffo (1985) and a new genus, Caledopisa, based on one new species. All specimens have been deposited in the Zoölogisch Museum, Amsterdam (ZMA). The remaining material, belonging to other families, will be treated in future.

The principal islands of New Caledonia include the mainland (Grande Terre), the Isle of Pines and the Loyalty Islands (Map A). Grande Terre is the largest island in the South Pacific after Papua New Guinea and New Zealand. It is located along the western margin of the Australian plate where it contacts the Pacific plate. Grande Terre is part of the same structural trend that has formed the northern peninsula of New Zealand to the south and the highlands of Papua New Guinea to the north.

The Isle of Pines (Map B) is separated from the main island of New Caledonia by a $43 \mathrm{~km}$ wide strait of shoals and coral banks. The island itself consists of a central cluster of highly eroded volcanic hills surrounded by a ring of karstified coralline limestone. Streams flowing off the impermeable volcanic hills typically disappear into caves as they enter the limestone. Sinkholes and limestone caves nearer to the coast reach anchihaline groundwater.

The Loyalty Islands (Map C) consist of a group of uplifted, late Tertiary coral reef islands situated atop a N.W.-S.E. trending volcanic ridge (Chevalier, 1975). This ridge runs parallel to the island of New Caledonia but is separated from it by a 130 $\mathrm{km}$ wide, $2000 \mathrm{~m}$ deep oceanic trough. On the other 


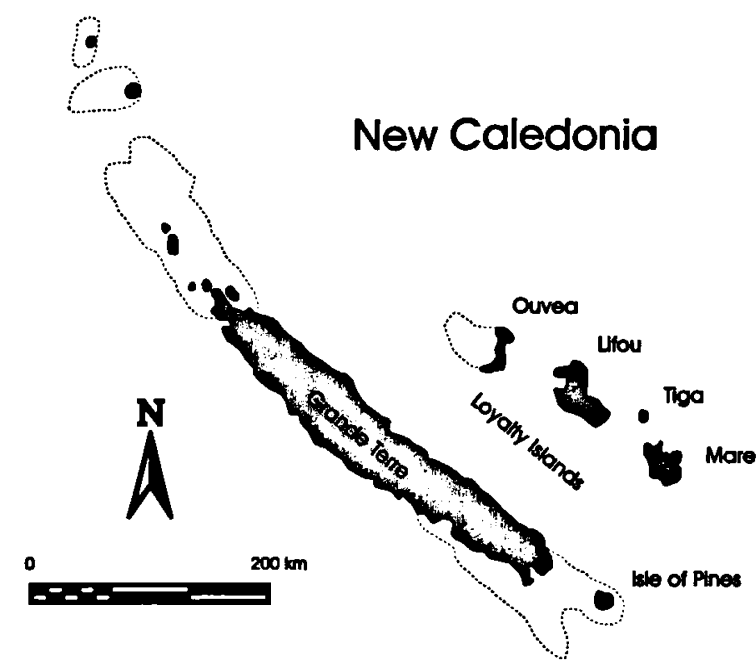

Map A. New Caledonia, showing locations of the Loyalty Islands and Isle of Pines.

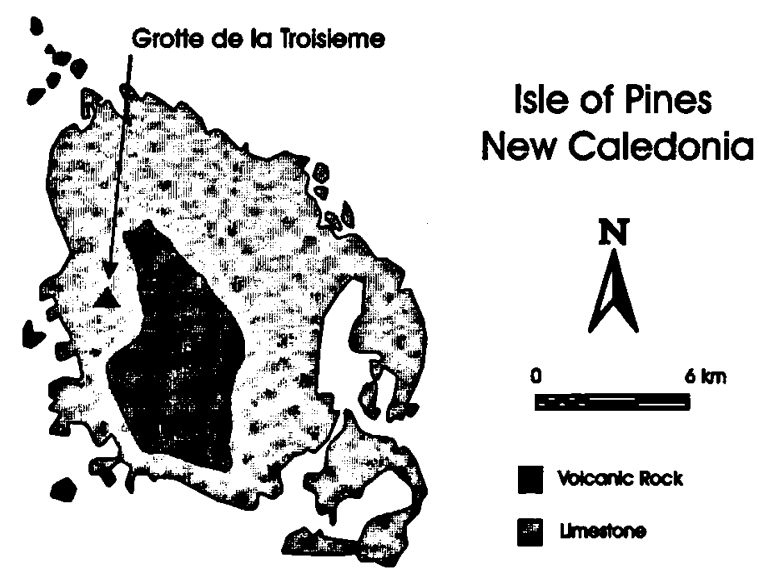

Map B. Isle of Pines, showing the location of Grotte de la Troisième (sta. 88/049).

side of the Loyalties, the New Hebrides Trench reaches depths of $7660 \mathrm{~m}$.

The islands of Lifou and Maré are emerged atolls, uplifted to $60 \mathrm{~m}$ elevation. Ouvéa is also an ancient atoll, but has been tilted to the west and is mostly submerged today. The oldest limestones on all three islands are probably of Miocene age. A series of eustatic terraces are also evident on all the islands. The numerous caves and deep sinkholes of the Loyalties are probably of Pleistocene age (Thomas, 1987).

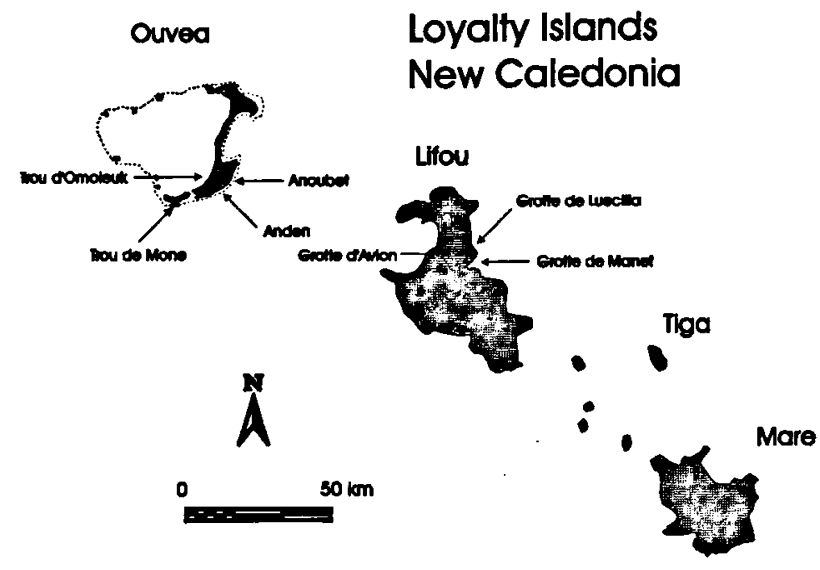

Map C. The Loyalty Islands, showing the locations of caves from which amphipods were collected.

\section{Taxonomy}

Genus Josephosella Ruffo, 1985

This genus was established for J. andamana Ruffo, 1985, from beach interstitia of South Andaman, Indian Ocean, and remained hitherto monospecific. Three new cave amphipods from New Caledonia appear to fit best in this genus, since they agree with the type-species in all 12 character states, including 7 synapomorphies, used in Table I. However, the genus does not have a single autapomorphic state, but the same holds true for almost all melitid genera. Several of the long-established genera appear to be a dumping ground for widely diverse species. The difficulties encountered, for instance, in distinguishing Melita and Abludomelita (see Karaman, 1981) have recently been exposed by Zeidler (1989) and Yamoto (1987, 1990). In the genus Josephosella, the distinctions from Melita and Paraniphargus are slight. Perusal of the literature on the melitids has made us aware that (1) many of the older descriptions are too incomplete to allocate certain species properly (the mouthparts are unknown or only partly known in these species), and (2) several species dumped in Melita s.l. appear to belong to other genera. Pertaining to the present study are a number of Pacific "Melita" species, such as $M$. awa Barnard, 1972a, M. oba Barnard, 1972b, M. celericula Croker, 1971, M. lignophila 
Table I. Distribution of character states $(0=$ plesiomorphic; $1=$ apomorphic) of genera of the "melitid-group" (see text).

\begin{tabular}{|c|c|c|c|c|c|c|c|c|c|c|c|c|c|}
\hline & genera & $J$ & $\boldsymbol{P}$ & Me & $\boldsymbol{A}$ & $\boldsymbol{T}$ & $M a$ & $\boldsymbol{A}$ & $\boldsymbol{G}$ & $\boldsymbol{V}$ & $C$ & $\boldsymbol{R}$ & $N$ \\
\hline & character state & & & & & & & & & & & & \\
\hline 1 & setation and size mandible palp & 1 & 1 & $\mathbf{0}$ & 0 & 1 & 1 & 0 & 1 & 0 & 1 & 1 & 1 \\
\hline 2 & segmentation mandible palp & 0 & $\mathbf{0}$ & 0 & 0 & 1 & 0 & 0 & 0 & 0 & 0 & 0 & 0 \\
\hline 3 & inner lobe maxilla 1 & 1 & 1 & 0 & 0 & 0 & 1 & 1 & 1 & 0 & 0 & 1 & 1 \\
\hline 4 & inner lobe maxilla 2 & $\mathbf{0}$ & 1 & $\mathbf{0}$ & 0 & $\mathbf{0}$ & 1 & 0 & 0 & 0 & 0 & 1 & 1 \\
\hline 5 & facial setae maxilla 2 & 1 & 1 & 1 & 0 & 1 & 1 & 1 & 1 & 0 & 1 & 1 & 1 \\
\hline 6 & basis $\mathrm{P7}$ & 1 & 1 & 1 & 1 & 1 & $\mathbf{0}$ & 1 & 1 & 0 & 1 & 1 & 0 \\
\hline 7 & peduncle U3 & 0 & 0 & 0 & 0 & 0 & 0 & 0 & 1 & 0 & 0 & 0 & 0 \\
\hline 8 & length U3 segment 2 & 1 & 1 & 1 & 1 & 1 & 1 & 1 & 1 & 0 & 1 & 1 & 1 \\
\hline 9 & U3 exopodite segment 2 absent & 0 & 1 & 1 & 0 & $\mathbf{0}$ & $\mathbf{0}$ & 1 & 1 & 0 & 0 & 0 & 0 \\
\hline 10 & flagellum segments $A 2$ & 0 & $\mathbf{0}$ & $\mathbf{0}$ & 0 & 0 & 0 & 0 & 0 & 1 & 1 & 0 & 0 \\
\hline 11 & accessory flagellum Al & 1 & 1 & 0 & 0 & 1 & 1 & 1 & 1 & 1 & 0 & 1 & 1 \\
\hline 12 & telson & 0 & $\mathbf{0}$ & $\mathbf{0}$ & 0 & 0 & $\mathbf{0}$ & $\mathbf{0}$ & 0 & 0 & 0 & 1 & 1 \\
\hline
\end{tabular}

$J=$ Josephosella; $P=$ Paraniphargus; $M e=$ Melita; $A=$ Abludomelita; $T=$ Tegano; $M a=$ Maleriopa; $A=A n c h i a l e l l a ; G=$ Galapsiellus; $V=$ Victoriopisa; $C=$ Caledopisa; $R=$ Rotomelita; $N=$ Nainaloa.

Barnard, 1961, M. sexstachya Gamô, 1977, $M$. somovae Bulyacheva, 1952, and M. plumulosa Zeidler, 1989, which may stand candidate for allocation in the genus Josephosella.

Traditionally, species with different structure of the propodus of the male gnathopod 2 are always united in one and the same genus. In the plesiomorphic type A, the claw fits the palmar margin, while in the apomorphic type B the claw overrides the palm. We have followed, somewhat reluctantly, this unanimous opinion, thus uniting in Josephosella species like $J$. andamana, microps $\mathrm{n}$. sp., and debilis n. sp. (type A), and J. proiecta n. sp. (type B). Among the "candidates" for Josephosella (see above), awa and oba belong to type A, celericula, somovae, and plumulosa fit type B. The male of $M$. sexstachya is unknown, so this species cannot be classified for the moment with either type A or B.

This seems to indicate that the melitids are still in need of a thorough revision. Hopefully some hardy soul, with access to material of most of the described taxa, will in future attempt to sort out their phylogeny. Arm-chair revisions were so far not quite successful in creating realistic phylogenetic units.

The character states of a number of closely related melitid genera, including the stygobiont taxa, are shown in Table I, using the family Gammaridae as outgroup. The following character states have been used $(0=$ plesiomorph, $1=$ apomorph $)$ :

(1) Mandible palp well developed; segment 2 with ventral armature; segment 3 with D- and E-setae (0).

Mandible palp regressed in size and armature; segment 2 completely or almost completely unarmed; segment 3 with E-setae only (1).

(2) Mandible palp 3-segmented (0). Mandible palp 2-segmented (1).

(3) Inner lobe of maxilla 1 with many setae, arranged on both medial and distal margins (0).

Inner lobe of maxilla 1 with reduced number of setae, on distal margin only (1).

(4) Inner lobe of maxilla 2 with setae on medial margin (0). Inner lobe of maxilla 2 without medial setae (1).

(5) Inner lobe of maxilla 2 with oblique (facial) row of setae (0). Inner lobe of maxilla 2 without oblique row of setae (1).

(6) Basis of pereiopod 7 with strong, overhanging posterodistal lobe (0).

Basis of pereiopod 7 slightly projecting or unlobed (1).

(7) Peduncle of uropod 3 much shorter than exopodite (0). Peduncle of uropod 3 80-100\% of length of exopodite (1).

(8) First and second segment of exopodite of uropod 3 subequal in length $(0)$.

Second exopodal segment of uropod 3 (if present) very much shorter than first (1).

(9) Second segment of exopodite of uropod 3 present (0). Second segment of exopodite of uropod 3 absent (1).

(10) Proximal flagellum segments of antenna 2 discrete (0). Proximal flagellum segments of antenna 2 fused (1).

(11) Accessory flagellum of antenna 14 - to 6-segmented (0). Accessory flagellum of antenna 12 - to 4-segmented (1).

(12) Telson lobes normally ovate or tapering (0). Telson lobes truncate, squarish (1). 


\section{Key to the species of Josephosella}

(Formally the genus consists of the type-species, J. andamana, and the three species described in this paper; for possible additional species, see above.)

1. Anterior half of coxal plate $6 \&$ bilobate. Finger of gnathopod 2 o overriding palm ..........J. proiecta $n$. sp.

- Anterior half of coxal plate 6 not bilobate. Finger of gnathopod 2 o fitting palmar margin ........... 2

2. Anterior half of coxal plate $6 \propto$ forming rounded lobe. Basis of pereiopod 7 o strongly tapering ......J. debilis n. sp.

- Anterior half of coxal plate $6 \%$ hook-shaped. Basis of pereiopod 7 not tapering, oval or elongate-oval ...... 3

3. Mandible palp segment 3 much shorter than segment 2. Basis of pereiopod 70 more than twice as long as wide, almost linear ..................... microps n. sp.

- Mandible palp segment 3 hardly shorter than segment 2. Basis of pereiopod $7 \sigma$ less than twice as long as wide, oval .................... J. andamana Ruffo, 1985.

\section{Descriptive part}

\section{Josephosella microps n. sp}

(Figs. 1-5)

Material. - Sta. 88/058: 1 o (holotype), 1 ovigerous $९$ (allotype), 78 paratypes of both sexes. New Caledonia, Loyalty Islands: Grotte de Luecilla, Lifou, anchihaline limestone cave, collected with plankton net from around wood and coconuts on bottom of pool, depth 0-1 m, salinity 1-3 ppt, 17 June 1988 (ZMA Amph. 201.637).

Grotte de Luecilla is located about $600 \mathrm{~m}$ inland from the east coast, west of the town of We and north of the main road leading to the airport. The cave is situated directly behind the home of Mme. Jone Monique in the village of Luecilla. A breakdown slope leads down from a $15 \mathrm{~m}$ wide collapse entrance to a clear, gravel and rubble floored pool. The pool is about $15 \mathrm{~m}$ long by $7 \mathrm{~m}$ wide with a maximum depth of $5 \mathrm{~m}$. Water level is $28 \mathrm{~m}$ below the surface of the ground. Salinity increased from $1 \mathrm{ppt}$ at the water surface to $3 \mathrm{ppt}$ at $5 \mathrm{~m}$. Water temperatures were constant at $22^{\circ} \mathrm{C}$. Shrimp and crabs were also collected from the pool, while a brown eel was observed.

Sta. 88/059: 102 specimens. New Caledonia, Loyalty Islands: Grotte d'Avion, Lifou, anchihaline limestone cave, collected with plankton net from wood and algae on bottom of pool, depth 0-3 m, salinity 0.5-1 ppt, 17 June 1988 (ZMA Amph. 201.636).

Grotte d'Avion is located about $1.3 \mathrm{~km}$ inland from the east coast, west of the town of We and north of the main road leading to the airport. It is situated behind a high school that has been converted into a French army camp. The cave consists of a 50 $m$ diameter collapse sinkhole that is mostly open at one end. A steep breakdown slope descends to a $30 \mathrm{~m}$ long by $8 \mathrm{~m}$ wide pool. Water depths in the clear pool exceed $10 \mathrm{~m}$. Under water, a large, horizontal, breakdown floored chamber extends away from the pool. Algal stalactites are present both under water and on the bedrock face above the pool. A luxuriant growth of algae is present along the edges of the pool. Water level is about $40 \mathrm{~m}$ below the surface of the ground. Salinity ranged from $0.5 \mathrm{ppt}$ at the surface to $1 \mathrm{ppt}$ at $10 \mathrm{~m}$. Water temperatures were constant at $22^{\circ} \mathrm{C}$.

Sta. 88/061: 2 specimens. New Caledonia, Loyalty Islands: Grotte de Manet, Lifou, anchihaline limestone cave, from coconut on surface, salinity 1 ppt, 20 June 1988 (ZMA Amph. 201.635).

Grotte de Manet is located $250 \mathrm{~m}$ inland from the east coast of Lifou about $3 \mathrm{~km}$ north of the town of We. The cave consists of a large, joint controlled, collapse cavern situated parallel to the coast at the base of the first line of cliffs. The entrance is a breakdown floored chasm about $20 \mathrm{~m}$ in diameter. Clear pools occur at opposite ends of the cavern. The southernmost pool is $\mathrm{U}$-shaped and about $\mathbf{4 0 - 5 0 ~} \mathrm{m}$ in total length. It extends along the walls of the cavern around a central breakdown mound. The bottom consists of large breakdown slabs with a thin layer of algae on those nearest the entrance. Water level is $12 \mathrm{~m}$ below the surface of the ground. Salinity increases from 1 ppt at the surface to $8 \mathrm{ppt}$ below a halocline at $9 \mathrm{~m}$. Water temperatures were constant at $22^{\circ} \mathrm{C}$. One shrimp was also collected from the pool.

Description. - Body (Fig. 1a) of both sexes c. 3 mm long, unpigmented. Eye (Fig. 1b) minute, in alcohol almost unpigmented (but in life perhaps red and decoloured in preservative). Dorsoposterior margin of all pereionites and all pleonites produced into minute pointed process. No spines or setae on dorsum. Ovigerous females bear low number (1 or 2) eggs; egg size $0.42-0.44 \times 0.29 \mathrm{~mm}$. Lateral head lobes not strongly projecting.

Antenna 1 (Fig. 1c) slender, at least as long as body, poorly setose; peduncle segment 2 longest; accessory flagellum short, usually 3-segmented (Fig. 1c, detail) but in some specimens only 2-segmented (Fig. 1d); flagellum of 20 or more segments; no aesthetascs. Antenna 2 (Fig. 1e) much shorter than antenna 1 , poorly setose. Slenderness of both antennae age dependent.

Upper lip (Fig. 1f) rounded. Lower lip (Fig. 1g) with poorly developed inner lobes. Mandible (Fig. $2 a, b)$ with 4-dentate left lacinia mobilis, and finely toothed right lacinia; long, plumose molar seta present on both sides; molar flake present; palp 

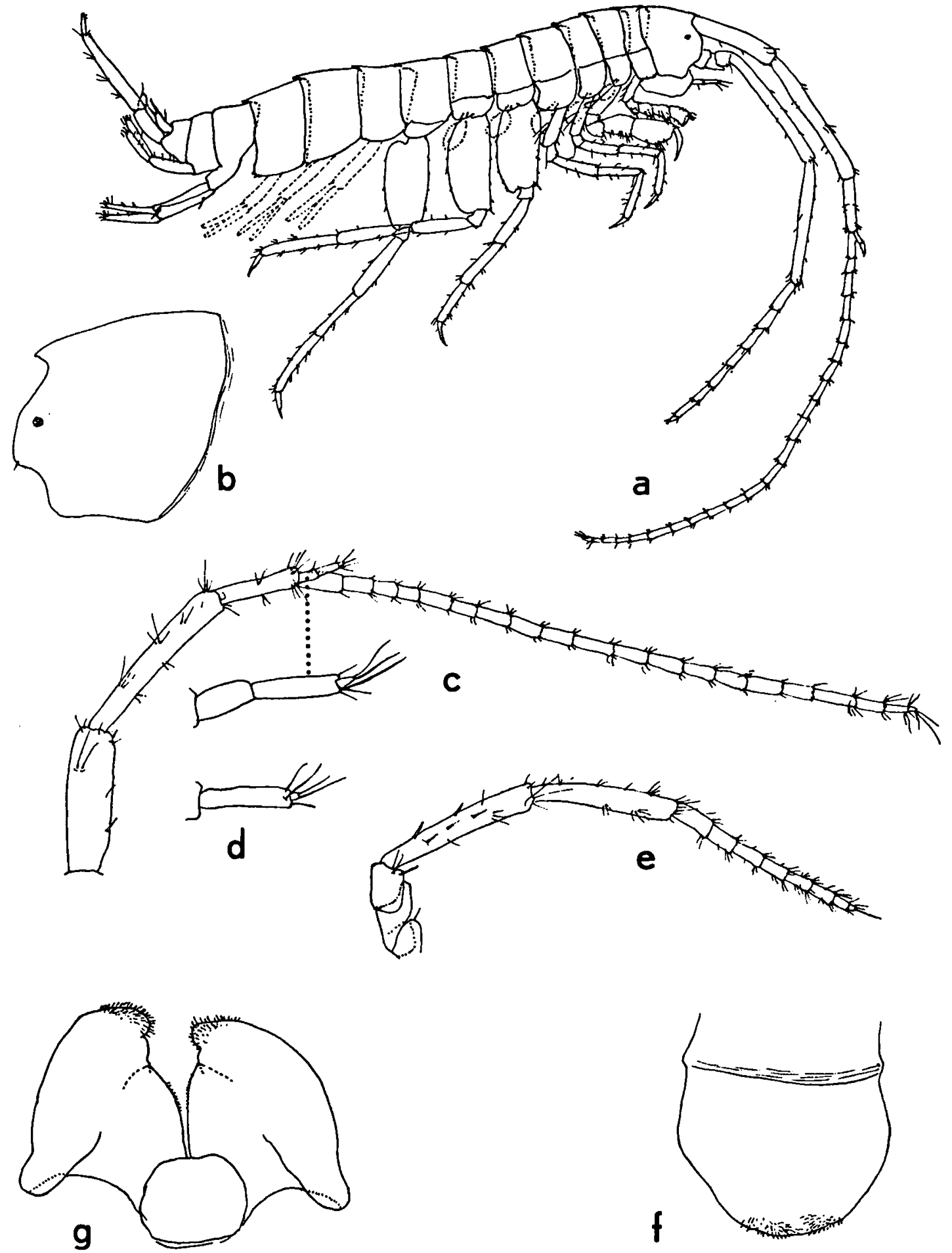

Fig. 1. Josephosella microps n. sp. ( $\sigma^{\circ}$ paratypes): a, entire animal from the right (scale 1); b, head, from the left (2); c, antenna 1 (3); d, accessory flagellum of antenna 1 of small male (4); e, antenna 2 (3); f, upper lip (4); g, lower lip (4). Scales on Fig. 5. 


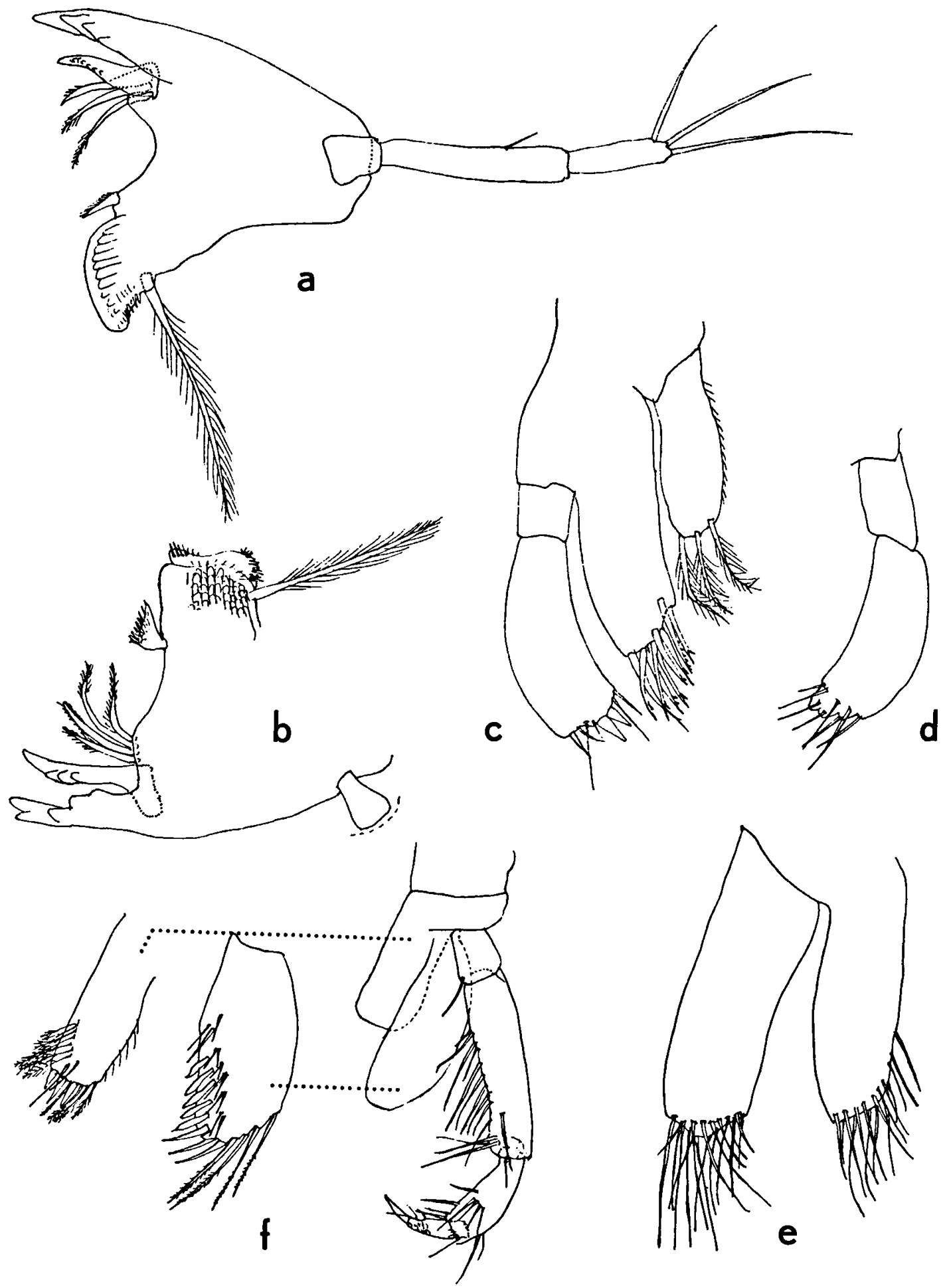

Fig. 2. Josephosella microps n. sp. (a-b: ९, c-f: $\sigma$; all paratypes): a, right mandible (scale 5); b, left mandible, palp omitted (5); c, right maxilla 1 (5); d, palp of left maxilla 1 (5); e, maxilla 2 (5); f, maxilliped (4). Scales on Fig. 5. 


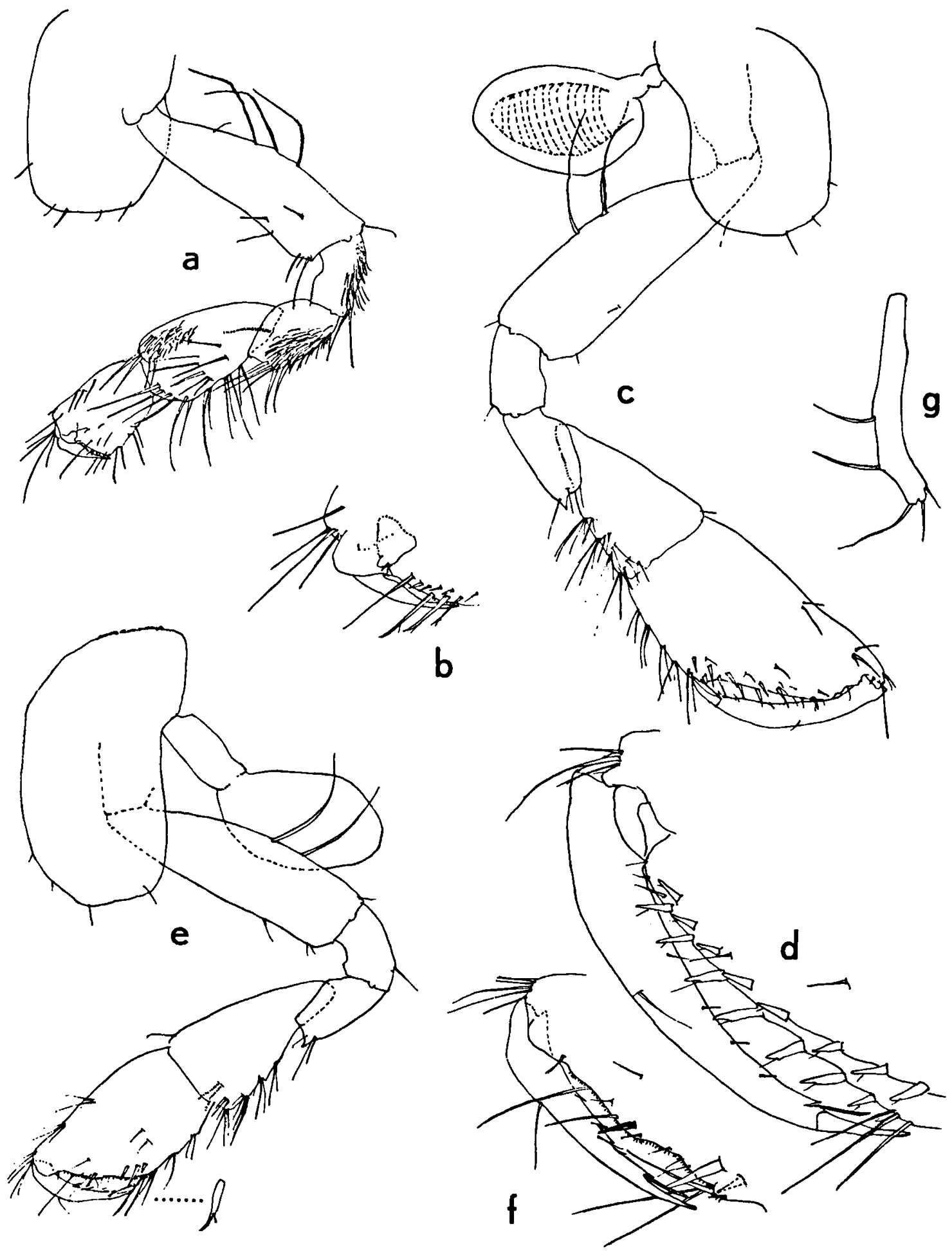

Fig. 3. Josephosella microps n. sp. (a-d: $\sigma^{\circ}$, e-g: $९$; all paratypes): a, gnathopod $1 \sigma^{\circ}$ (scale 6); b, palma of gnathopod $1 \sigma^{\circ}$ (2); c, gnathopod 2 o (6); d, palma of gnathopod 2 o (5); e, gnathopod 2 (6) (mid-palmar spine more strongly enlarged); f, palma of gnathopod 2 \% (5); g, oostegite of gnathopod 2 \% (6). Scales on Fig. 5. 

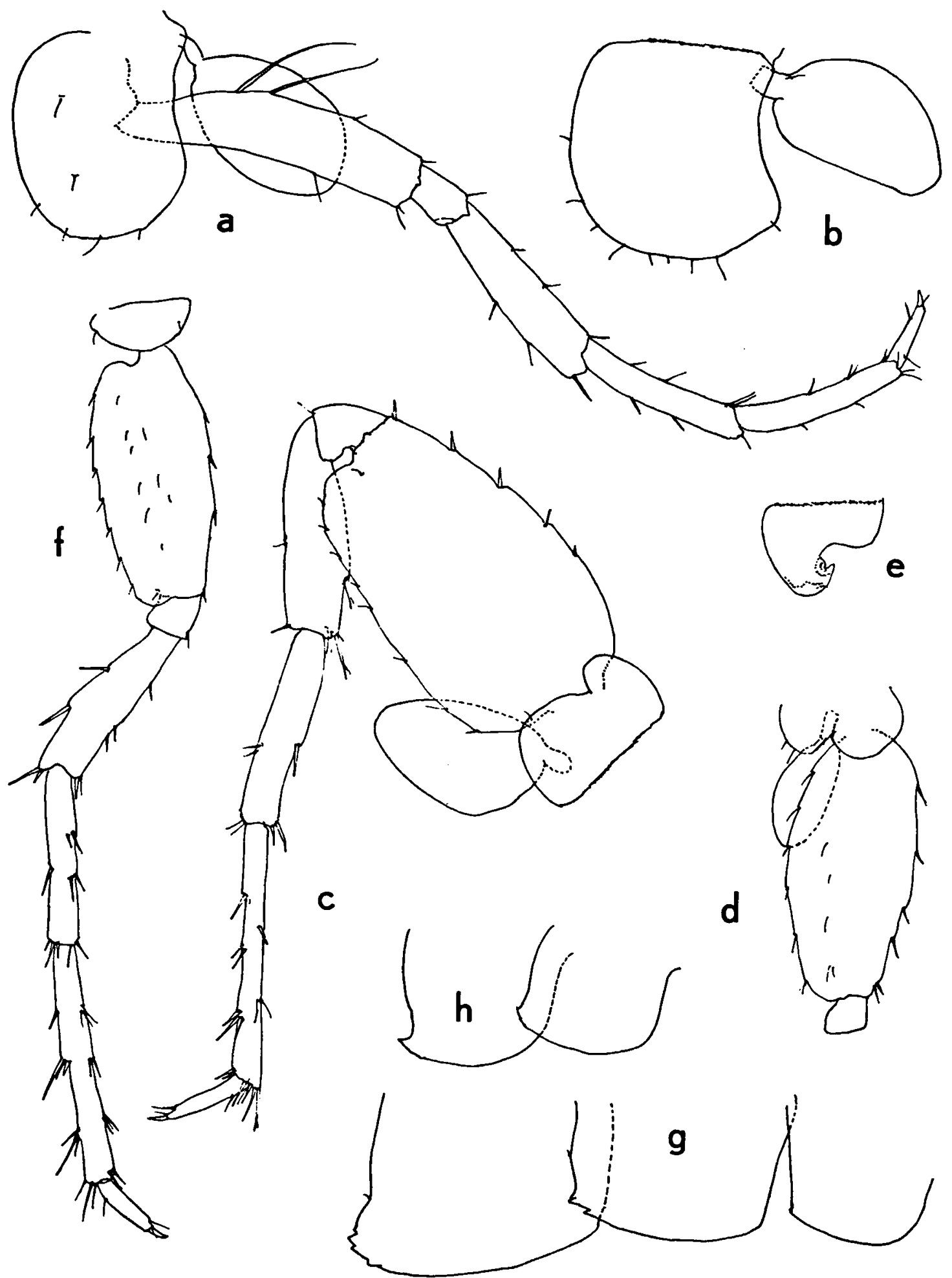

Fig. 4. Josephosella microps $\mathrm{n}$. sp. (paratypes, all from $\sigma$, except for Fig. 4e): a, pereiopod 3 (scale 6); b, coxal plate and gill of pereiopod 4 (6); c, pereiopod 5 (6); d, basal part of pereiopod 6 (2); e, coxal plate of pereiopod 6 (2); f, pereiopod 7 (2); g, epimeral plates 1 to 3, from the right (2); h, epimeral plates 2 and 3 of smaller $\sigma$ (2). Scales on Fig. 5. 


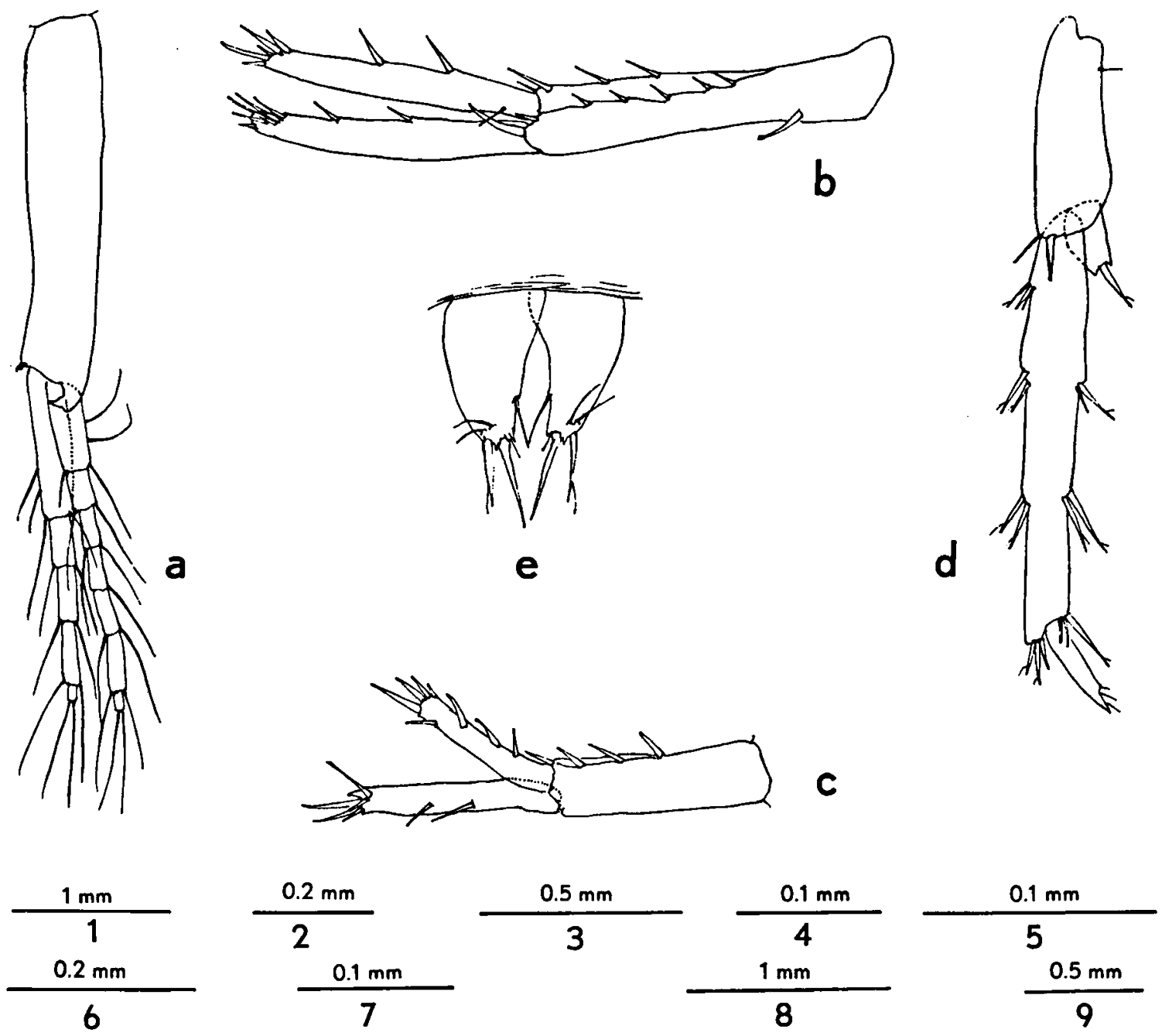

Fig. 5. Josephosella microps n. sp. (o paratype): a, pleopod 1 (scale 6); b, uropod 1 (6); c, uropod 2 (6); d, uropod 3 (6); e, telson (4).

reduced in size and armature, 3-segmented. Maxilla 1 (Fig. 2c, d): palp slightly asymmetrical; outer lobe with 9 spines of which 8 uni- or bidentate, and one with 6 teeth; inner lobe thump-shaped, with 3 distal setae. Maxilla 2 (Fig. 2e) lacking oblique row of setae on inner lobe; medial margin of inner lobe with setae in distal part. Maxilliped (Fig. 1f) with 3 spines on inner lobe; palp, especially segment 3 , narrow, slender.

Gnathopod 1 (Fig. 3a): carpus longer than propodus; palmar margin with 4 setae and some setules, no palmar angle spine (Fig. 3b).

Gnathopod $2 \sigma^{\circ}$ (Fig. 3c) with large propodus; finger not overriding; palmar margin with 2 rows of
7 or 8 short spines; palmar angle marked by 3 setae (Fig. 3d). Gnathopod 2 \% (Fig. 3e): propodus not much longer than carpus; palmar margin with 2 angle spines, 1 short mid-palmar spine and minute setules (Fig. 3f).

Pereiopod 3 (Fig. 4a) poorly setose. Coxal plate 4 wider than plate 3 , posterior margin concave (Fig. $4 \mathrm{~b}$ ); distal segments of pereiopod 4 similar to those of pereiopod 3. Coxal plates 1 to 4 with some short setae on lower margin; all plates of similar length.

Pereiopod 5 (Fig. 4c) armed with few, short spines. Pereiopod $6 \sigma^{\circ}$ (Fig. 4d) with bilobate coxal plate; anterior lobe of coxal plate $\$$ transformed into hook (Fig. 4e); distal segments as in pereiopod 
7. Pereiopod 7: coxal plate unlobed; basis elongateelliptical, posterodistal corner rounded, somewhat produced.

Coxal gills present on gnathopod 2 and pereiopods 3 to 6 , distinctly pedunculate on anterior legs, smaller and less clearly pedunculate on posterior legs. Oostegites (Fig. 3g) very narrow, armed with few (about 5) setae.

Epimeral plates 2 and 3 of larger specimens (Fig. $4 \mathrm{~g}$ ) with 1 or 2 serrations on ventroposterior margin; serrations obsolete in smaller specimens; none of plates with ventral spines. Pleopods (Fig. 5a) with smooth peduncle; laterodistal end of peduncle with process in shape of bird-head; 2 retinacula, bearing 2 or 3 pairs of teeth. Number of segments in rami fluctuating between 5 and 7 .

Uropod 1 (Fig. 5b) with proximoventral peduncular spine; dorsal margin of rami with 2 spines. Uropod 2 as illustrated (Fig. 5c). Uropod 3 (Fig. 5d): peduncle at least 3 times as long as wide; exopodite 2-segmented, armed with spines only; endopodite small, with 1 terminal spine.

Telson (Fig. 5e) cleft, each lobe tapering, with 2 distal spines, 1 short medial seta, and 2 sensory setules near distal end.

Etymology. - The specific name, microps (Greek: with small eyes) is self-evident.

Remarks. - Members of the genus Paraniphargus Tattersall, 1925, containing 2 blind freshwater species from the Andaman Islands and Sunda (Indonesia) are distinguished from Josephosella only in the apomorphic loss (1) of medial setae on the inner lobe of maxilla 2 and (2) of the distal segment of the exopodite of uropod 3, resulting in the conclusion that Josephosella is only weakly characterized by plesiomorphies.

\section{Josephosella debilis n. sp.}

(Figs. 6-8)

smc.

Material. Is'Sta. 88/067: $1 \propto$ (holotype), 1 ovigerous 9 (allotype), 6 paratypes ( $Q \odot$ and juvs.). New Caledonia, Loyalty Islands: Anden, Ouvéa, anchihaline limestone cave, collected with dip net from submerged coconuts along edge of pool, depth 0-0.3 m, salinity $1.5 \mathrm{ppt}, 22$ June 1988 (ZMA Amph. 201.640).

Anden is located about $800 \mathrm{~m}$ inland from the east coast near the start of the forest trail to Anoubet. This $15 \mathrm{~m}$ diameter, $6 \mathrm{~m}$ deep sinkhole is located adjacent to a limestone quarry. Numerous palm trees grow from the flat, soil floor of the sink. Two shallow, mud-bottomed pools are present along the sides of the sink. Salinity was 1.5 ppt. Podocopid ostracods (Darwinula sp., Kennethia major, Paracypria sp.), and copepods were also collected.

Sta. 88/062: 66 specimens. New Caledonia, Loyalty Islands: Trou de Moné, lle de Mouly, anchihaline limestone cave, collected with plankton net from the water column and silty sediments, depth 0-0.5 m, salinity 15 ppt, 21 June 1988 (ZMA Amph. 201.641).

Trou de Mone is located $500 \mathrm{~m}$ inland from the coast and south of the village of Mouly on Ile de Mouly in Ouvéa. The cave consists of a $30 \mathrm{~m}$ diameter, $5 \mathrm{~m}$ deep, flat-floored sinkhole situated in a coconut grove. Two shallow open pools containing large amounts of organic detritus extend along the sides of the sink. Salnity was 15 ppt. Podocopid ostracods (Mungava sp.), shrimp, isopods, gastropods, and copepods were also collected.

Sta. 88/063: 32 specimens. New Caledonia, Loyalty Islands: Trou d'Omoleuk \#1 (or Omolek), Ouvéa, anchihaline limestone cave, collected with plankton and dip nets, depth $0-0.5 \mathrm{~m}$, salinity 1.5 ppt, 22 June 1988 (ZMA Amph. 201.642).

Trou d'Omoleuk \#1 is located $1.8 \mathrm{~km}$ inland from the coast of Ouvéa near the village of Ouloup. The cave is situated at the eastern edge of the road which runs south from the Airport. It is a $2 \mathrm{~m}$ wide by $5 \mathrm{~m}$ deep fissure with a $5 \mathrm{~m}$ long, $2 \mathrm{~m}$ wide and $1 \mathrm{~m}$ deep pool at the bottom. The floor of the murky pool consists of algal-covered rocks and black silt. Surface salinity and water temperature were $1.5 \mathrm{ppt}$ and $22.5^{\circ} \mathrm{C}$. Large numbers of shrimp and copepods were also collected from the pool.

Sta. 88/064: 2 ơ $\sigma, 3$ १, 4 juvs. New Caledonia, Loyalty Islands: Trou d'Omoleuk \#2, anchihaline limestone cave, depth 0-0.3 m, collected with plankton and dip nets from mud bottom, salinity 3 ppt, 22 June 1988 (ZMA Amph. 201.644).

Trou d'Omoleuk \#2 (or Omolek) is located $1.8 \mathrm{~km}$ inland from the coast of Ouvéa near the village of Ouloup. The cave is situated on the opposite side of the road from Trou d'Omoleuk \#1 (sta. 88/063). It is a circular sinkhole, about $10 \mathrm{~m}$ in diameter and $5 \mathrm{~m}$ deep. This sinkhole is partially soil filled, with a shallow pool, $5 \mathrm{~m}$ long by $2.5 \mathrm{~m}$ wide along one side. The bottom of the pool consists of soil and dark silt. Maximum depth in the murky pool is about $70 \mathrm{~cm}$. Large numbers of shrimp and copepods were also collected from the pool.

Sta. 88/066: More than 70 specimens. New Caledonia, Loyalty Islands, Anoubet, Ouvéa, anchihaline limestone cave, collected with plankton net from water column of larger pools, depth 0-3 m, salinity 5 ppt, 22 June 1988 (ZMA Amph. 201.643).

Anoubet is located $400 \mathrm{~m}$ inland from the east coast, east of the village of Ouloup. This cave is situated on the inland side of an old, uplifted barrier reef. The entrance sinkhole is $30 \mathrm{~m}$ in diameter and $10 \mathrm{~m}$ deep to water level. A pool at the south end is mostly open to daylight. This pool, which curves around the edges of the central breakdown cone, is $60 \mathrm{~m}$ long and $10 \mathrm{~m}$ wide. Maximum water depth is $8 \mathrm{~m}$. The bottom consists of rubble with some sunken tree limbs and coconuts. A second pool in 
total darkness lies at the opposite end of the cave. Salinity and temperature were $5 \mathrm{ppt}$ and $22.5^{\circ} \mathrm{C}$. Podocopid ostracods (Heterocypris sp., Kennethia major, Paracypria sp.), copepods, shrimp, crabs, and fish were also collected from the pools.

Description. - Body of preserved specimens without pigmentation, length of male specimens $3 \mathrm{~mm}$, of ovigerous females $2.7 \mathrm{~mm}$; latter with few, 1 to 3, eggs. Eye large, for the greater part pigmented, black in preserved state, but sometimes with some unpigmented ocelli. Lateral head lobe triangular (Fig. 6a). Armature of dorsum as in $J$. microps, but with small mid-dorsal tooth on urosomite 1 (size of teeth variable, in $\sigma^{*}$ larger than $q$ or juv., see also paragraph on variability).

Antenna 1 (Fig. 6b) more than half as long as body, very setose; peduncle segment 2 longest, flagellum 18-segmented; no aesthetascs; accessory flagellum 3-segmented, short. Antenna 2 (Fig. 6c) about $2 / 3$ of length of antenna 1 ; very setose; flagellum 9-segmented; no calceoli.

Upper lip (Fig. 6d) wider than long. Lower lip (Fig. 6e) with small but distinct inner lobes. Left mandible with short, plumose molar seta and 4-dentate lacinia mobilis (Fig. 6f), right mandible sometimes with molar seta and with bicuspidate lacinia (Fig. 6g). Mandible palp (Fig. 6f) regressed, very short; segments 1 and 2 unarmed, segment 3 short, with 1 long distal seta (but see paragraph on variability). Maxilla 1 (Fig. 6h) with long, slender palp; outer lobe with 9 spines, medialmost spine flat; one of the spines pluridentate, other spines with 2 or 3 denticles; inner lobe rectangular, with 7 plumose setae. Maxilla 2 (Fig. 7a): inner lobe with medial setae. Maxilliped (Fig. $7 b-d$ ): palp slender; outer lobe reaching to $80 \%$ of length of palp segment 2; inner lobe with 2 mediodistal spines.

Gnathopod 1 (Fig. 7e): carpus longer than propodus; propodus mitten-shaped; palmar margin sinuous (Fig. 7f).

Gnathopod $2 \sigma^{\prime}$ (Fig. 7g) with triangular carpus and elongate-oval propodus; palmar margin sinuous, armed with some longer and some very short setae; palmar angle with 4 setae (Fig. $7 \mathrm{~h}$ ). Claw fitting palmar margin. Gnathopod 2 (Fig. 7i) with trapezoidal carpus and rectangular propodus; palmar angle with 2 setae and 2 spines; 1 small midpalmar spine.
Pereiopod 3 as in Fig. 8a. Pereiopod 4 with rectangular, non-excavate coxal plate (Fig. 8b). Pereiopod 5 shorter than pereiopod 6; posterodistal corner of basis produced but not overhanging (Fig. 8c). Pereiopod 6 almost as long as pereiopod 7; posterodistal corner of basis less produced than in pereiopod 5; coxal plate 6 of both $\sigma^{\circ}$ and $\$$ bilobate (Fig. 8d, f). Pereiopod 7 with almost unproduced posterodistal corner of basis (Fig. 8e).

Coxal gills more or less distinctly stalked, large on gnathopod 2, successively smaller on pereiopods 3 through 6. Oostegites (Fig. 7j) very narrow, armed with 5 setae.

Epimeral plates 1 to 3 (Fig. 8g) with weakly notched or serrate ventral margin; plates 2 and 3 with pointed posterior corner. Pleopods (Fig. 8h): peduncle unarmed, but for 2 minute retinacula; distolaterally with bifid projection; rami long, 10-segmented, all setae plumose, except 2 most proximal setae on medial margin of endopodite.

Uropod 1 with strong proximoventral peduncular spine; rami with only 2 short dorsal setae (Fig. 8i). Uropod 2 as in Fig. 8j. Uropod 3 (Fig. 8k) with small but distinct second exopodal segment; peduncle 2.5-3 times as long as wide. Telson cleft, lobes tapering and pointed; each lobe with 1 lateral and 1 or 2 distal spines; 2 sensory setules implanted near base of lateral spine (Fig. 8-1).

Etymology. - The specific name, debilis (Latin: powerless) alludes to the regressed condition of the mandible palp.

Remarks. - Differs from $J$. microps and J. andamana at first sight by the much better developed eye and by the strongly setose antennae 1 and $2 . J$. debilis bridges to a certain extent the gap between Melita and Josephosella. It shares the regressed mandible palp with the latter, but the inner lobe of maxilla 1 is more setose and more Melita-like. The eyes are also larger than in any other Josephosella, although they are partly depigmented.

At the moment, we feel that the structure of the mandible palp outweighs the other characters, and classify this species with Josephosella.

Variability. - The above description is based on 


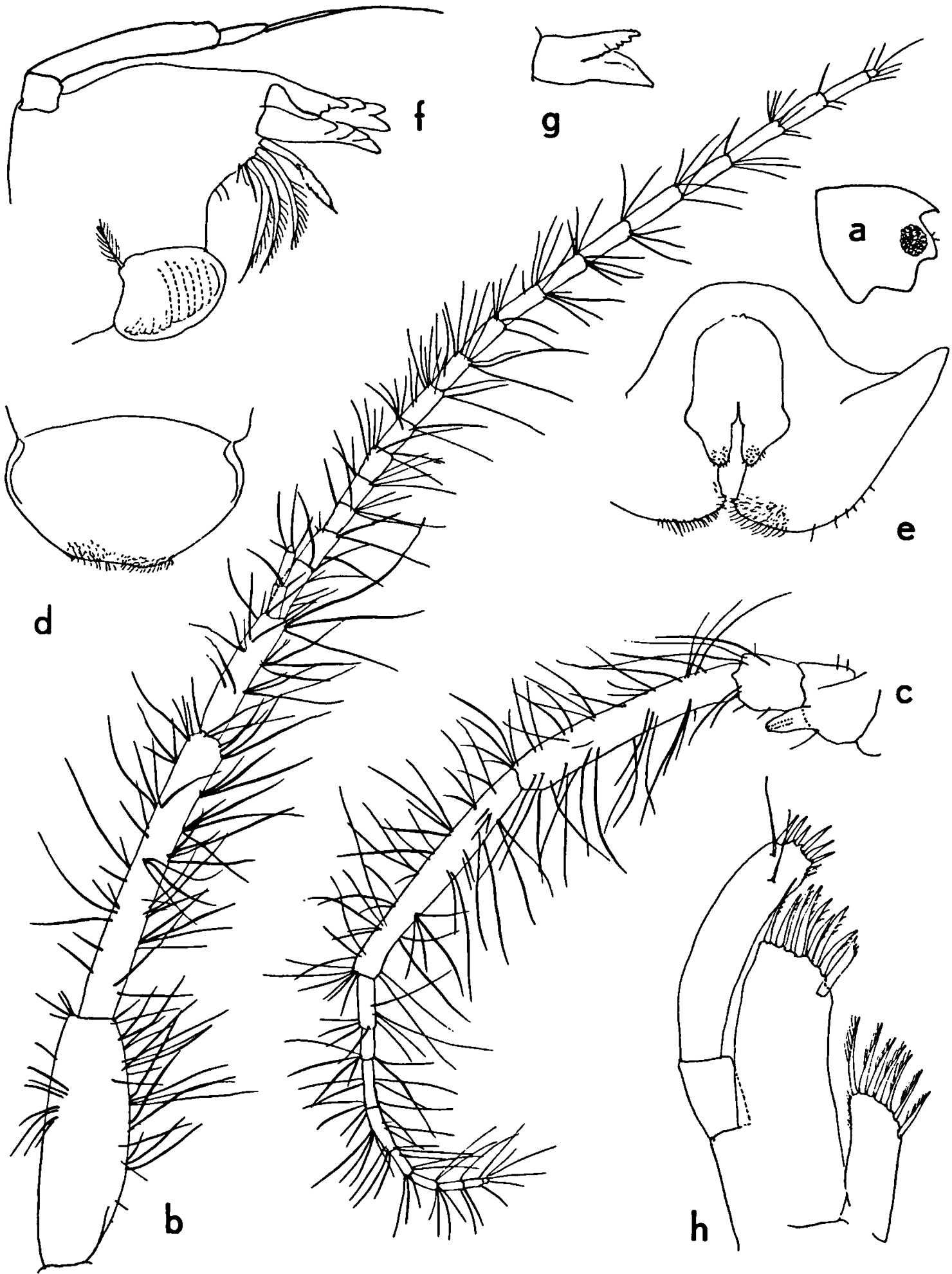

Fig. 6. Josephosella debilis n. sp. (a: $\$$ paratype, b-h: 0 holotype): a, head, from the right (scale 3); b, antenna 1 (2); c, antenna 2 (2); d, upper lip (4); e, lower lip (4); f, left mandible (5); g, right lacinia mobilis (5); h, left maxilla 1 (5). Scales on Fig. 5. 


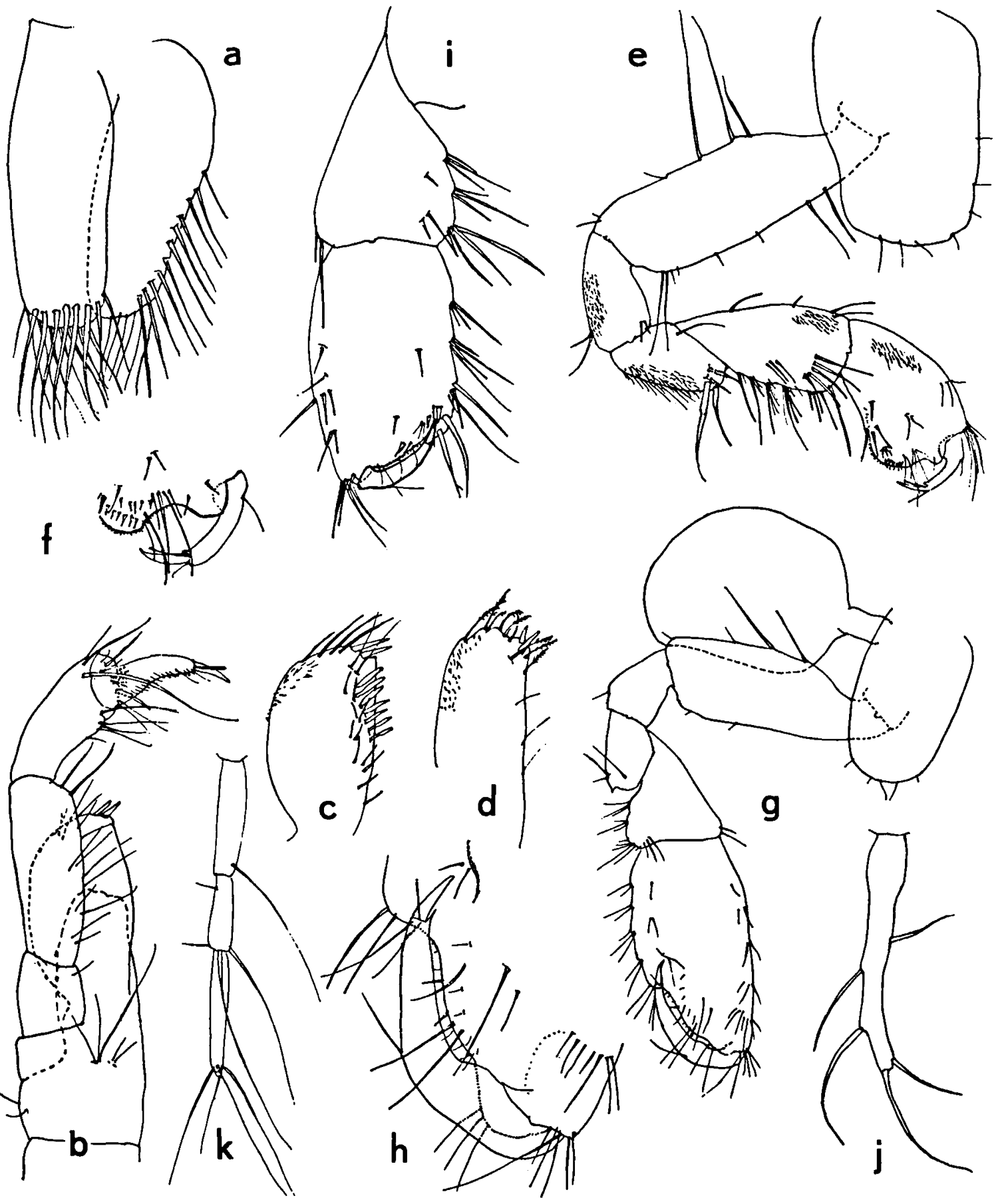

Fig. 7. Josephosella debilis $\mathrm{n}$. sp. (a-h: $\sigma$ holotype, $\mathrm{i}-\mathrm{j}$ : $९$ paratype, k: $\sigma$ from sta. 88/063): a, maxilla 2 (scale 5); b, maxilliped (4); c, outer lobe of maxilliped (4); d, inner lobe of maxilliped (4); e, gnathopod 1 (6); f, palma of gnathopod 1 (7); g, gnathopod 2 (2); h, palma of gnathopod 2 (4); i, carpus and propodus of gnathopod 2 (4); j, oostegite of gnathopod 2 (6); $k$, accessory flagellum of antenna 1 (4). Scales on Fig. 5. 


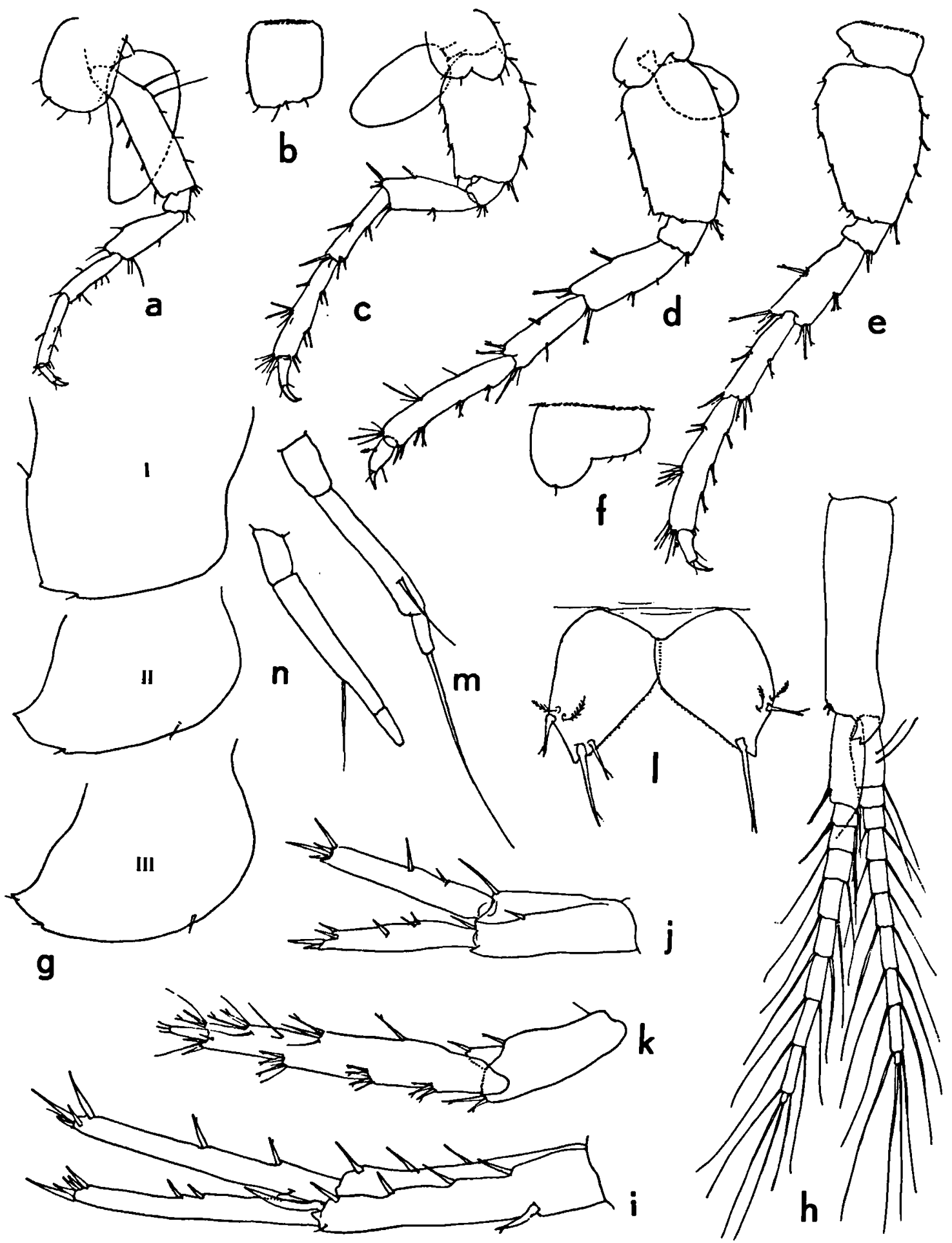

Fig. 8. Josephosella debilis n. sp. (f: $९$ paratype; a-e, g-1: $\sigma$ holotype; $\mathrm{m}-\mathrm{n}$ : $९$ from sta. 88/063): a, pereiopod 3 (scale 3); b, coxal plate of pereiopod 4 (3); c, pereiopod 5 (3); d, pereiopod 6 (3); e, pereiopod 7 (3); f, coxal plate of pereiopod 6 (2); g, epimeral plates 1 to 3 (6); h, pleopod 1 (plumosity of setae omitted) (6); i, uropod 1 (6); j, uropod 2 (6); $k$, uropod 3 (2); 1, telson (4); m, n, variations in mandible palp (5). Scales on Fig. 5. 
the material from sta. 88/067. The population of sta. 88/066 consists of very small specimens ( $O$ up to $2.7 \mathrm{~mm}$, ovigerous $92.2 \mathrm{~mm}$ ). The morphology of the appendages is very similar in the two populations. The only noteworthy difference resides in the almost complete suppression of the small teeth on the dorsum of pereion, pleosome, and urosome in the animals from sta. 88/066.

The numerous specimens from sta. 88/063 are much larger (maximum body length 5.5-6 mm) and show incipient pigmentation. The accessory flagellum is longer, reaching to the middle of flagellum segment 3 , and consists of up to 4 segments (Fig. 7k). The mandible palp is variable (Fig. $8 \mathrm{~m}$, $\mathrm{n})$ : the terminal segment may be armed with 1 long seta (as in the illustrated male from sta. 88/067, see Fig. 6f), or unarmed; segment 2 may carry 1 ventral seta (no setae in sta. 88/067). The inner lobe of maxilla 1 bears up to 9 setae, and the palp is slightly wider. The inner lobe of the maxilliped is armed with 2 to 4 spines. The posterior margin of the third epimeral plate sometimes bears 1 setule. The third uropod shows a more elongate first exopodite segment. Probably these differences are mostly age(= size-) dependent.

Specimens from stations 88/062 and 064 are very similar. They are slightly less pigmented than those of sta. 88/063 and have smaller eyes.

\section{Josephosella proiecta n. sp.}

(Figs. 9-12)

Material. - Sta. 88/063: $1 \sigma$ (holotype), $1 \propto$ (allotype), $9 \circ \sigma$ and $4 \& \&$ (paratypes). New Caledonia, Loyalty Islands: Trou de Moné, Ile de Mouly, anchihaline limestone cave, collected with plankton net from water column and silty sediments, depth 0-0.5 m, salinity 1.5 ppt, 22 June 1988 (ZMA Amph. 201.638). See for details about the locality under $J$. debilis.

Description. - Body unpigmented, length of male $5.5 \mathrm{~mm}$, of ovigerous female $5 \mathrm{~mm}$. Eye (Fig. 9a, b) rather small; ommatidia, especially in centre of eye, degenerated, of very different sizes, unpigmented in preserved state. Dorsum of body smooth, except for urosomite 1 (with pair of minute setules) and urosomite 2 (with pair of spiniform processes) (Fig. 12e). Ovigerous female bearing 2 eggs only.
Lateral head lobes rounded (Fig. 9a). Antenna 1 (Fig. 9c) in general not unlike that of J. microps, but accessory flagellum very short (shorter than first flagellum segment), 2-segmented; flagellum 17-segmented. Antenna 2 (Fig. 9d) not setose; gland cone pointed, almost triangular in lateral view; flagellum 9-segmented.

Upper lip (Fig. 9e) broadly rounded. Lower lip (Fig. 9h) with poorly developed inner lobes. Mandible palp emaciated; segments 1 and 2 unarmed; segment 3 with 3 terminal setae only (Fig. 9f); left lacinia mobilis 4-dentate, right lacinia bicuspidate, finely denticulate (Fig. 9g); molar left and right with short, plumose seta. Maxilla 1 with asymmetrical palp: left palp narrow, with 5 slender distal spines +4 setae, right palp broad, with 6 short distal spines +4 setae (Fig. 9i, j); outer lobe with 9 distal spines, six of which bear numerous fine denticles on inner margin, the remaining three bear 0 to 3 denticles; inner lobe ovate with 8 graduated plumose setae on distal margin. Armature of maxilla 2 resembling that of $J$. microps. Maxilliped differing from that of $J$. microps in wider distal palp segments and less thin distal claw (Fig. 9k); inner lobe with 4 spines.

Gnathopod 1 (Fig. 10a) not sexually dimorphic; propodus (Fig. 10b) slightly curved; 2 short palmar angle spines. Gnathopod 2 or (Fig. 10c) with huge, bulgy propodus; finger overriding palm; palm with very reduced armature; coxal gill very large. Gnathopod 2 (Fig. 10d) with small propodus, finger not overriding palm.

Pereiopod 3 (Fig. 11a) with straight coxal plate; coxal gill large. Pereiopod 4 with distinct posterior emargination on coxal plate (Fig. 11b). Pereiopod 5 damaged in all males at hand; in female (Fig. 11c) with posterolobate, subrectangular basis. Basis of pereiopod 6 (Fig. 11d) also with posterodistal lobe; coxal plate 6 sexually dimorphic: in $\$$ the anterior part consists of 2 small rounded lobes (Fig. 11e), in $\sigma$ of 1 large, broadly rounded lobe. Pereiopod 7 also sexually dimorphic: in $\sigma^{\circ}$ anterior margin of basis distally produced into strong point (Fig. 12a), in $\$$ anterior margin not produced (Fig. 12b); the basis has a feeble posterodistal lobe $\left(\sigma^{\circ}, q\right)$.

Epimeral plates 2 and 3 (Fig. 12c, d) with weakly produced ventroposterior corner; lower margin 


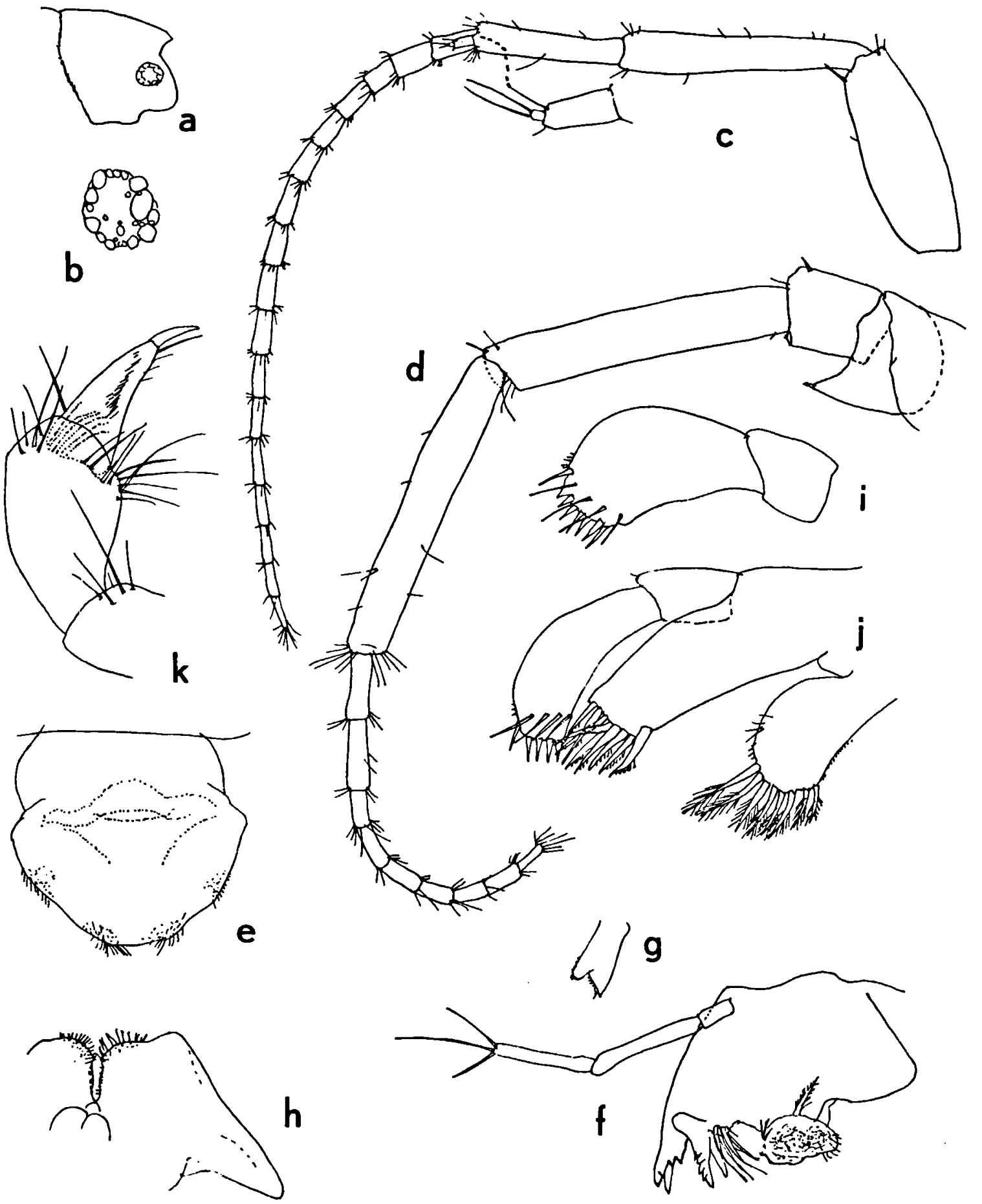

Fig. 9. Josephosella proiecta n. sp. ( $\sigma^{\circ}$ paratype): a, head, from the right (scale 8); b, eye (2); c, antenna 1 (3); d, antenna 2 (4); e, upper lip (6); f, left mandible (6); g, right lacinia mobilis (6); h, lower lip (6); i, palp of right maxilla 1 (4); j, left maxilla 1 (4); $k$, distal segments of maxillipedal palp (4). Scales on Fig. 5. 


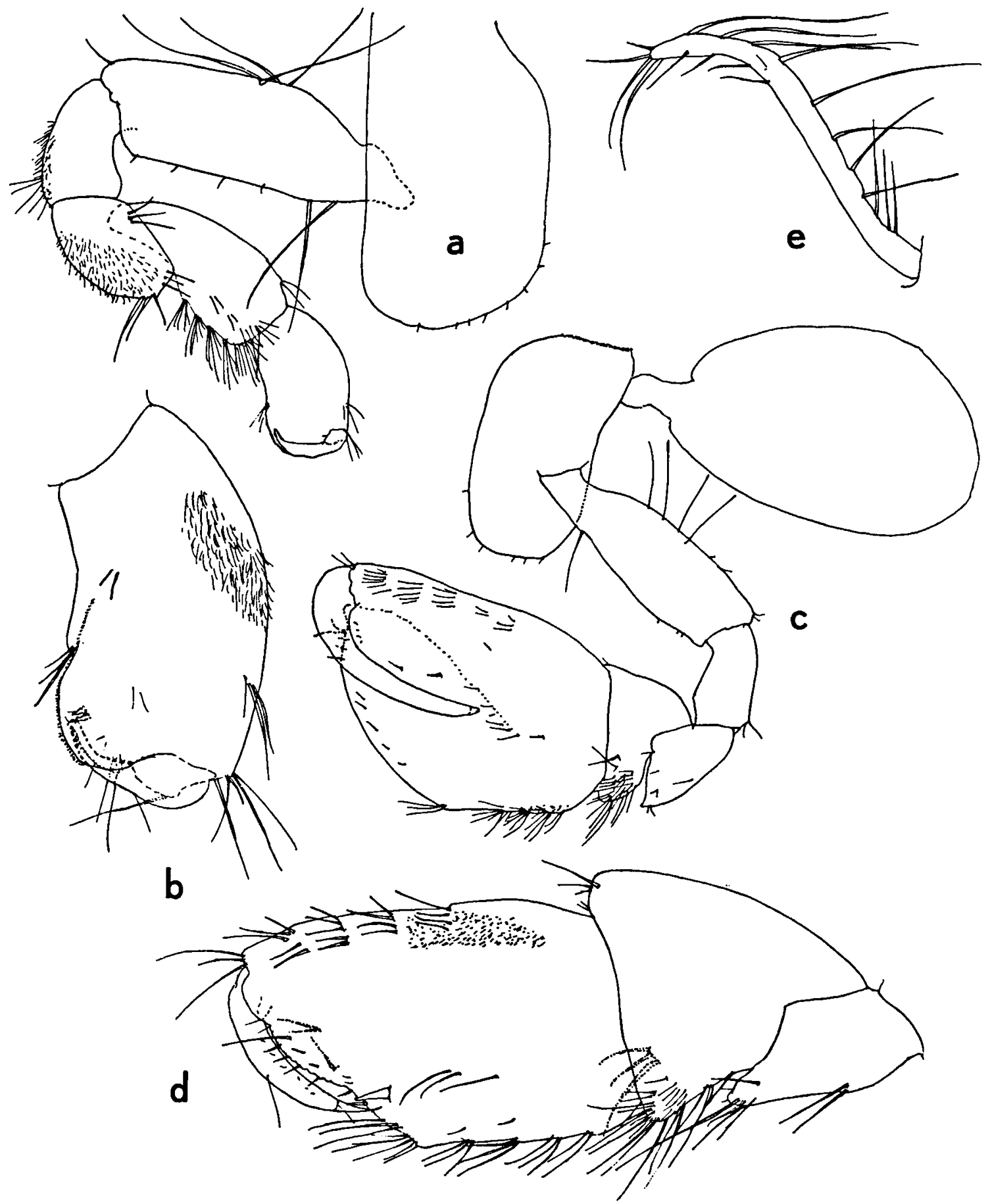

Fig. 10. Josephosella proiecta $\mathrm{n}$. sp. (a-c: $\sigma, d-\mathrm{d}:$ : ; all paratypes): a, gnathopod 1 (scale 2); b, propodus of gnathopod 1 (4); c, gnathopod 2 (3); d, distal segments of gnathopod 2 (6); e, oostegite of gnathopod 2 (2). Scales on Fig. 5. 


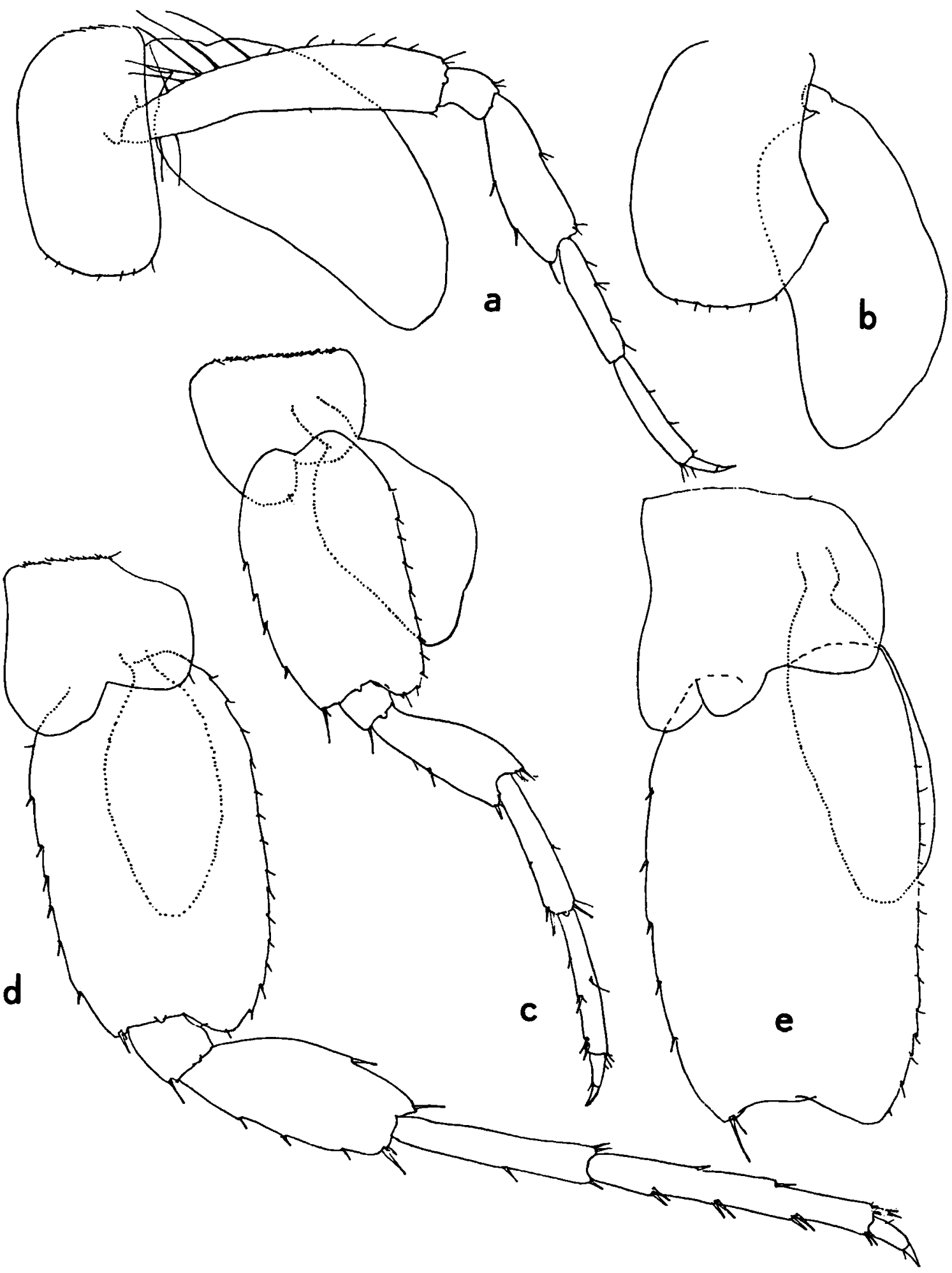

Fig. 11. Josephosella proiecta n. sp. (c and e: $\$$, remaining figures $\sigma$; all paratypes): a, pereiopod 3 (scale 3); b, coxal plate and gill of pereiopod 4 (3); c, pereiopod 5 (3); d, pereiopod 6 (3); e, basal part of pereiopod 6 (2). Scales on Fig. 5. 

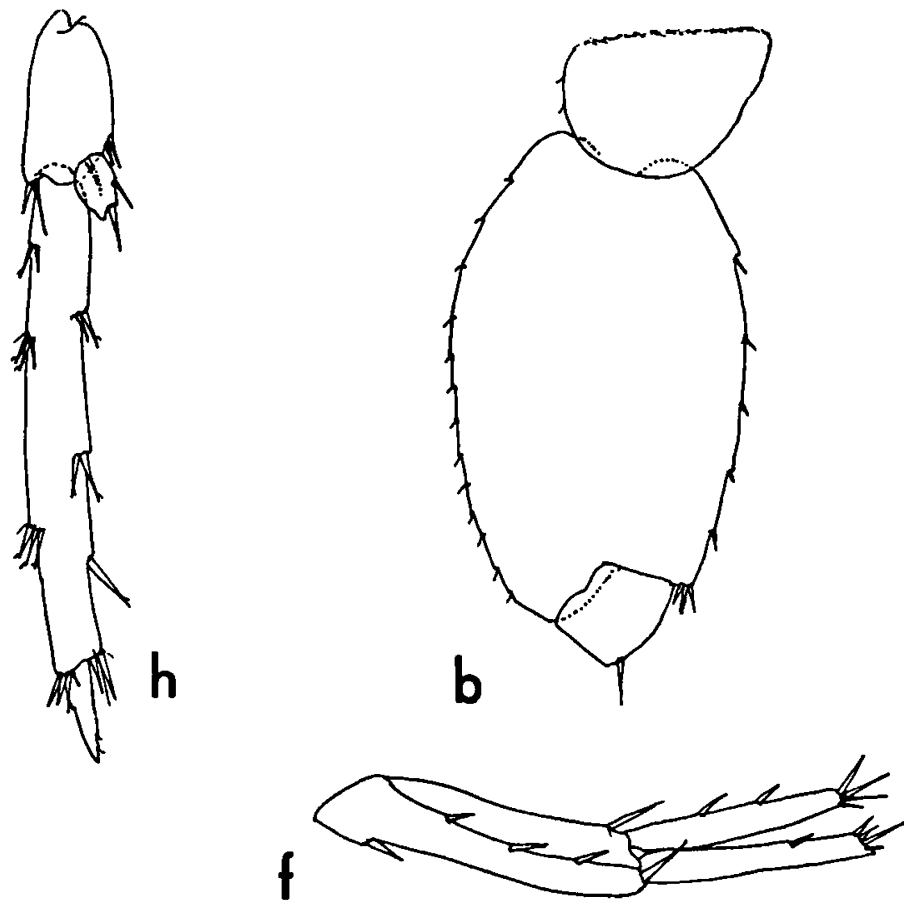

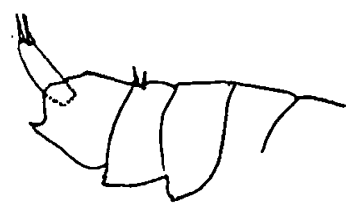

e

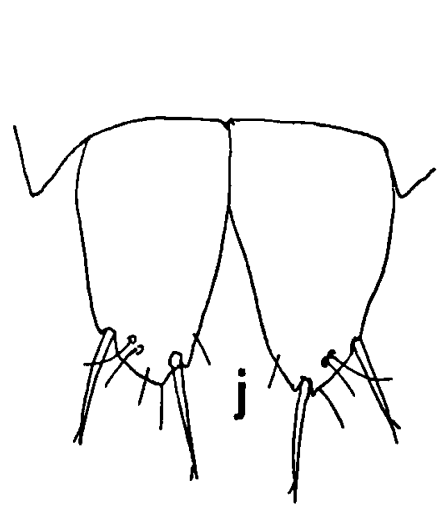

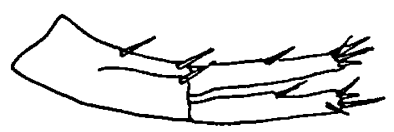

g

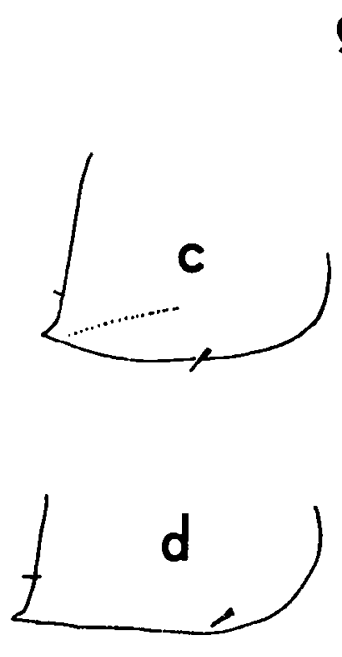

\section{g}
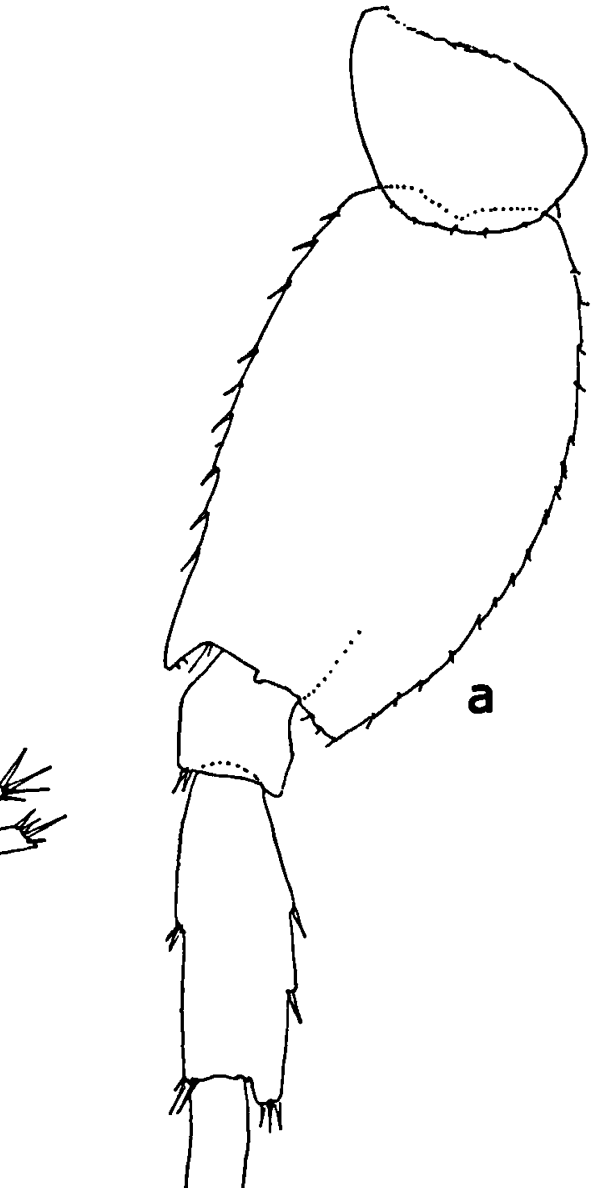
with 1 spine; posterior margin with 1 setule. Pleopodal rami much longer than peduncle, 12- to 13-segmented; 2 retinacula, each with 4 pairs of teeth. Projection on distal end of outer margin of peduncle as illustrated (Fig. 12i).

Uropod 1 (Fig. 12f) with proximoventral peduncular spine; outer ramus with 0 or 1 dorsal spine, inner ramus with 2 dorsal spines. Uropod 2 (Fig. 12g) with 1 dorsal spine on each ramus. Uropod 3 (Fig. 12h) peduncle not elongate; outer ramus long, 2-segmented; 2nd segment well developed. Telson (Fig. 12j) with egg-shaped lobes, each lobe with 2 distal spines and some setules.

Coxal gills on legs 2 through 6 , frontal gills largest. Oostegites (Fig. 10e) on legs 2 through 5, very narrow, ribbon-shaped.

Etymology. - The specific name, proiecta (Latin), alludes to the distal projection on the basis of pereiopod 7 in males.

Remarks. - The unpigmented body, the reduction in eye-size and the regression of the ommatidia, as well as the low number of eggs, are clearly adaptations to cave environments. On the other hand, the great development of the male propodus in gnathopod 2 links the species with epigean melitids. In particular, it resembles "Melita"' awa Barnard, 1972, an estuarine species from New Zealand, but this species differs mainly in the shape of the anterior lobe of coxal plate $6 \%$, the absence of a strong anterodistal point on the basis of pereiopod $7 \sigma^{\circ}$, and the presence of lateral spines on the telson.

There is also some resemblance to the Australian species Melita oba Barnard, 1972 and M. mathilda Barnard, 1972, but here again, coxal plate $6 \%$ is at once distinctive. In addition, the non-lobate basis of pereiopods 5 to 7 serves to distinguish M. mathil$d a$, and the strongly setose propodus of gnathopod $2 \sigma^{\circ}$ to distinguish $M$. oba.

\section{Caledopisa a. gen.}

Diagnosis. - Melitidae belonging to the Melita group (sensu Barnard \& Barnard, 1983: 376).

Accessory flagellum of antenna 1 long, 4-seg- mented. Proximal segments of flagellum of antenna 2 fused. Molar seta of mandible reduced; left lacinia mobilis 4-dentate; palp strongly reduced in size and armature; palp segment 3 with one long terminal seta, sometimes accompanied by a smaller seta. Lower lip with well-developed inner lobes. Maxilla 1: left and right palp almost identical, inner lobe with setae on both distal and medial margins. Maxilla 2 without oblique (facial) row of setae on inner lobe. Coxae 1 to 4 of about same length. Gnathopod 1 mitten-shaped. Tip of finger of gnathopod $2\left(\sigma^{\circ}, \%\right)$ overriding inner surface of propodus. Basis of pereiopods 5 to 7 hardly projecting. Pleopods not sexually dimorphic. Uropod 3 parviramous; exopodite 2-segmented. Telson almost completely cleft, telson lobes tapering.

Type-species. - Caledopisa levis n. sp.

Etymology. - Caledopisa is a merger of the terra typica, New Caledonia, and Eriopisa, one of the classical genera of the Melitidae. The specific name, levis (Latin: unmeaning), alludes to the regressed mandible palp.

Remarks. - The only melitid genus sharing the apomorphic condition of fused proximal flagellum segments of antenna 2 is Victoriopisa Karaman \& Barnard, 1979. We agree with Morino (1991) that Roropisa Karaman, 1984 is a subjective synonym of Victoriopisa. Caledopisa differs mainly from this genus in the non-lobate basis of pereiopod 7, in the absence of an oblique row of setae on the inner lobe of maxilla 2 , in the regressed mandible palp, in the reduced size of the second exopodite segment of uropod 3, and in the longer, 4-segmented accessory flagellum of antenna 1.

Caledopisa levis n. sp.

(Figs. 13-15)

Material. - Sta. 88/049: 1 o (holotype), 1 ovigerous \& (allotype), 22 paratypes. New Caledonia: Grotte de la Troisième, Isle of Pines, anchihaline limestone cave, depth 0-6 m, salinity 1.5-11.5 ppt, 1 June 1988 (ZMA Amph. 210.639).

Grotte de la Troisième (sta. 88/049), also known as Paradise Cave, is an anchihaline limestone cave located about $2 \mathrm{~km}$ inland 
from the west coast of the Isle of Pines. The cave was named for members of the Third Paris Commune who were imprisoned on the Isle of Pines between 1871 and 1879. From the $10 \mathrm{~m}$ diameter collapse entrance, breakdown slopes descend to two interconnected pools, each with a surface area of about $50 \mathrm{~m}^{2}$. All sections of the cave are well decorated with large stalactites, stalagmites and columns. Water level in the pools is about $12 \mathrm{~m}$ below the surface of the ground. The water is very clear with a surface temperature and salinity of $21^{\circ} \mathrm{C}$ and $1.5 \mathrm{ppt}$. At $6 \mathrm{~m}$, the deepest point in the pool, values were $22^{\circ} \mathrm{C}$ and $11.5 \mathrm{ppt}$. No underwater passages were found extending away from the pool. In shallower water, the bottom is flowstone and rubble, with thick silt present at deeper depths. Also collected from the cave pool were mysids (Speleomysis sp.), ostracods (Kennethia major), shrimp, copepods, and anthurid isopods.

Description. - Body unpigmented, maximum length of male $6 \mathrm{~mm}$, of female $5 \mathrm{~mm}$. Eye small, with many ocelli, central ocelli pigmented, marginal ocelli loosing pigment (Fig. 13a). Dorsum without teeth or spines. Ovigerous female with few (1 to 4) eggs. Lateral head lobe rather prominent; infra-antennal sinus distinct (Fig. 13a).

Antenna 1 (Fig. 13b) about as long as body; peduncle segment 2 very long and slender; peduncle segments 1 and 2 with short setules only, longer setae on peduncle segment 3 and flagellum; flagellum $\left(\sigma^{*}\right)$ with up to 34 segments, without aesthetascs; accessory flagellum 4-segmented.

Antenna 2 ( $\left.O^{*}\right)$ (Fig. 13c) with almost smooth peduncle; peduncle segments 4 and 5 very elongate; proximal (7?) flagellum segments fused into single elongate segment, almost half as long as peduncle segment 5; all flagellum segments (= basal fusion complex +5 free segments) with setae, longest of which slightly longer than diameter of segment; no calceoli. Antenna $2 \%$ weaker than that of $O$.

Upper lip (Fig. 13d) with almost straight distal margin. Lower lip (Fig. 13g) with well-developed inner lobes. Mandible (Fig. 13e) with 6-dentate pars incisiva; left lacinia mobilis 4-dentate, right lacinia bifid (Fig. 13f); no molar flake; molar seta plumose, very short, present only on left mandible; mandible palp regressed, not overreaching tip of pars incisiva; segment 2 more than twice as long as segment 3, unarmed or with 1 distal seta; segment 3 with 1 distal seta, almost as long as entire palp, sometimes accompanied by 1 short seta. Maxilla 1 (Fig. 13h): outer lobe with 9 spines, lateralmost of which with 1 denticle, medialmost flattened, with several fine denticles, central spines 3-dentate; inner lobe with 8 setae on distal and distomedial margins; left and right palp almost symmetrical. Maxilla 2 (Fig. 13i) ordinary; inner lobe without oblique row of setae. Maxilliped (Fig. 13j): outer lobe reaching to $2 / 3$ of second palp segment; inner lobe with 3 spines; palp with long dactylus and short unguis.

Gnathopod 1 (Fig. 14a) with rugose patches on merus, carpus, and propodus; carpus. $\gg$ propodus; palmar angle with 1 spine, palmar margin with some spinules and setules (Fig. 14b). Gnathopod 2 (Fig. 14c, e) with sexual dimorphism in carpus and propodus. Carpus $\%$ longer than wide, not much shorter than propodus; propodus weak, with 1 palmar angle spine (Fig. 14f); finger not overriding palm. Carpus $\sigma^{\circ}$ at most half as long as propodus, as long as wide; no palmar angle spines, but 1 midpalmar spine (Fig. 14d). Distal part of finger overriding palm.

Coxal plate 3 rectangular (Fig. 14g); coxal plate 4 slightly wider than plate 3 , posterior margin not emarginate (Fig. 14i). Remaining segments of pereiopods 3 and 4 similar. Pereiopod 5 (Fig. 15a) shorter than pereiopod 6; basis posterodistally produced; merus and carpus spinous and with some short setae. Basis of pereiopod 6 (Fig. 15b) with somewhat concave posterior margin; posterodistal corner less produced than in P5; coxal plate sexually dimorphic (regularly bilobate in $\sigma^{\circ}$, anterior lobe sinuous in $\%$, Fig. 15c); distal segments similar to those of P7. Pereiopod 7 (Fig. 15d) with non-lobate coxal plate; basis wider than in $\mathrm{P6}$, posterodistal corner hardly produced.

Coxal gills weakly pedunculate, present on gnathopod 2 and pereiopods 3 through 6 . Oostegites (Fig. 14h) linear, with low number of setae.

Epimeral plates 1 to 3 (Fig. 15e) with 1 or 2 denticles on ventral margin; plate 2 with 1 , plate 3 with 2 ventral spines. Pleopods (Fig. 15f) with 12to 15-segmented rami; proximal endopodite segment with 2 medial spines, other segments with 2 plumose setae; peduncle with some medial setae; 2 retinacula, with 3 pairs of teeth; laterodistal end of peduncle with irregularly shaped process.

Uropod 1 (Fig. 15g) with proximoventral pedun- 


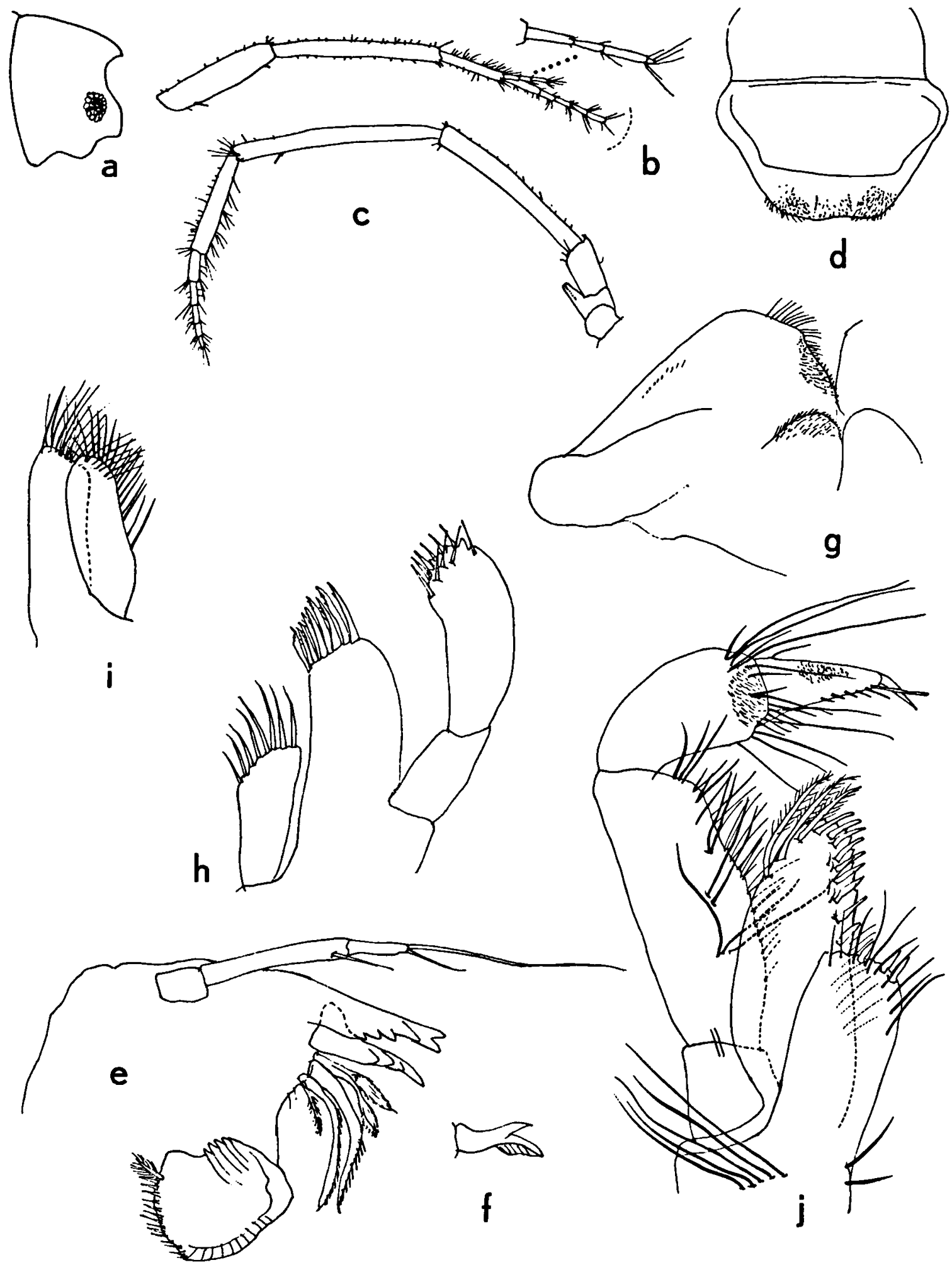

Fig. 13. Caledopisa levis n. gen., n. sp. ( 0 holotype): a, head, from the right (scale 8); b, antenna 1 (1); c, antenna 2 (9); d, upper lip (6); e, left mandible (4); f, right lacinia mobilis (4); g, lower lip (4); h, left maxilla 1 (4); i, maxilla 2 (6); j, maxilliped (4). Scales on Fig. 5. 


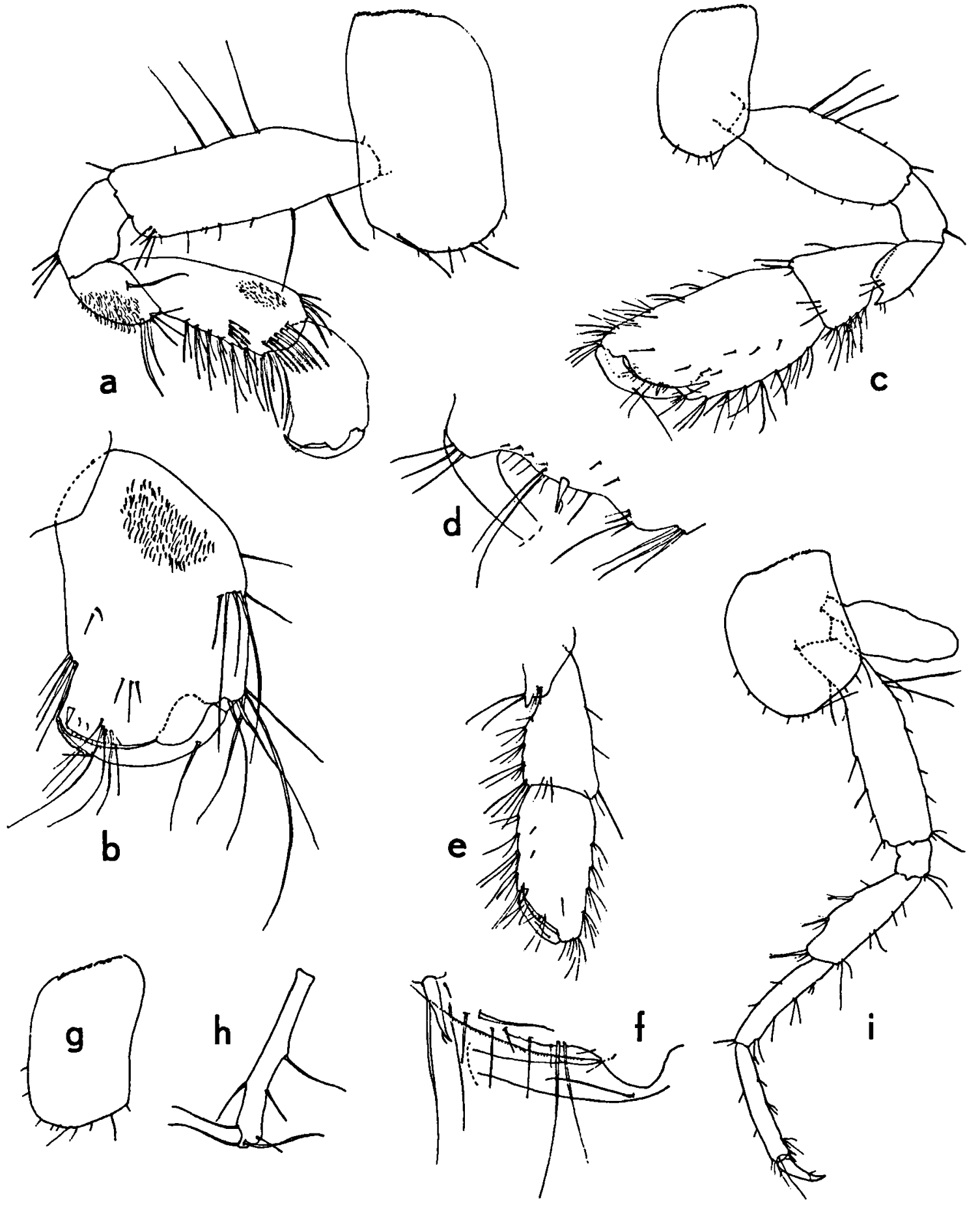

Fig. 14. Caledopisa levis n. gen., n. sp. (e, f, and h: $९$ paratype, remaining figures $\sigma^{\circ}$ holotype): a, gnathopod 1 (scale 2); b, propodus of gnathopod 1 (4); c, gnathopod 2 (3); d, palma of gnathopod 2 (6); e, distal segments of gnathopod 2 (2); f, palma of gnathopod 2 (5); g, coxal plate 3 (3); h, oostegite of pereiopod 3 (2); i, pereiopod 4 (5). Scales on Fig. 5. 

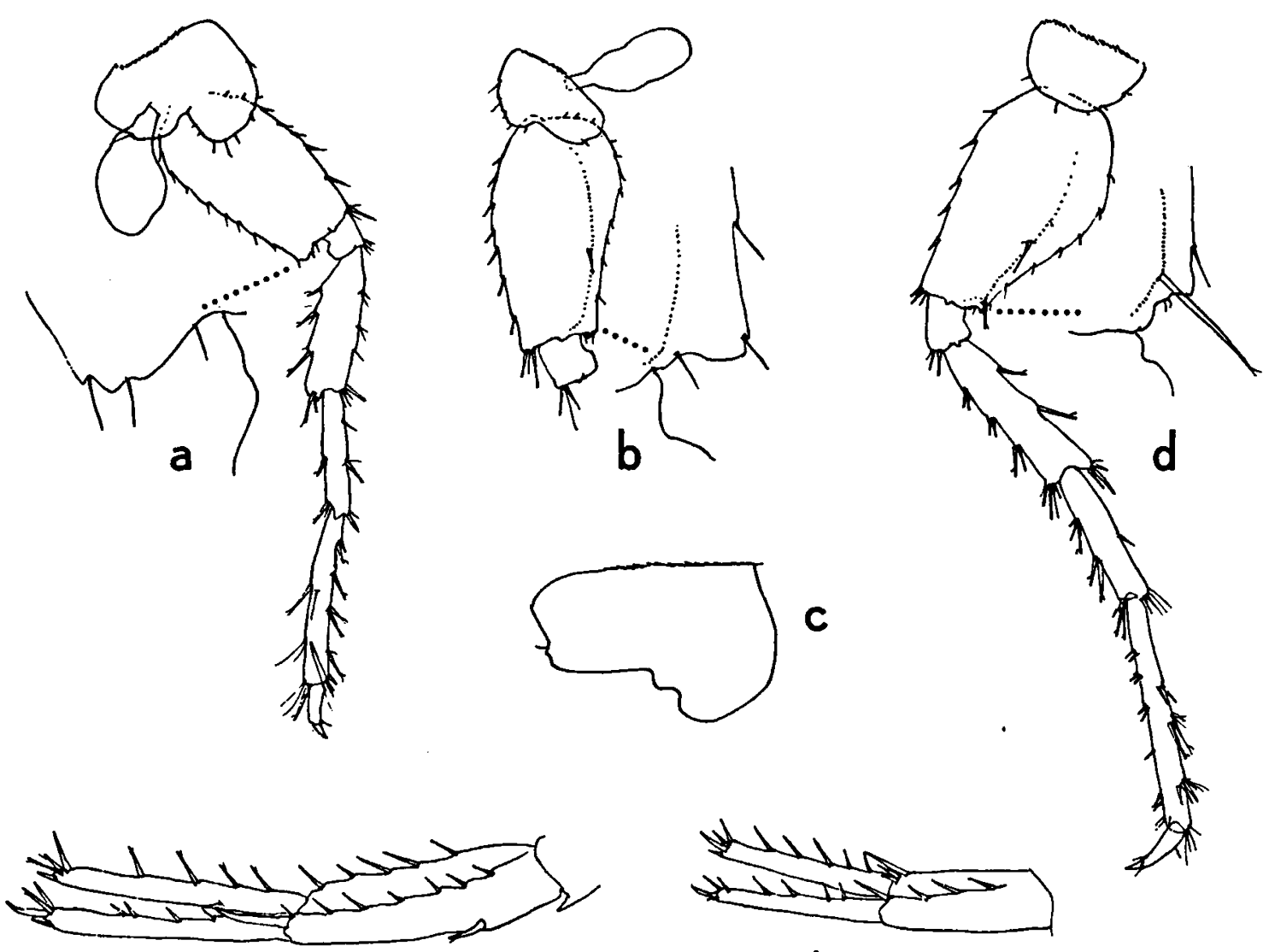

h

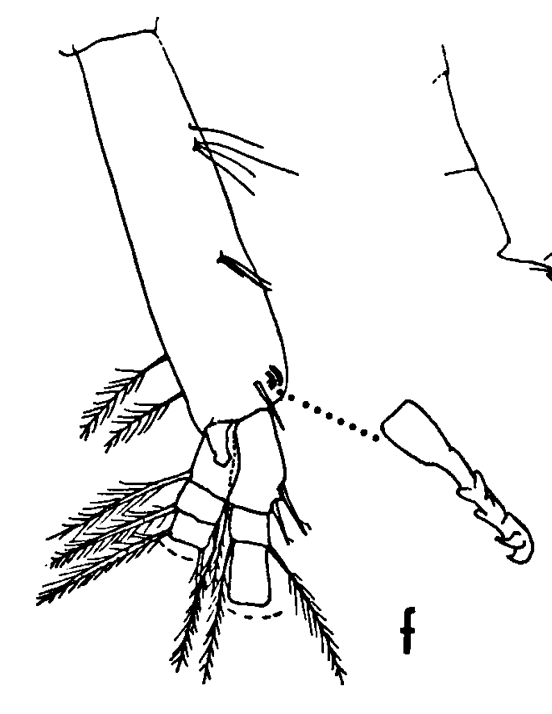

g

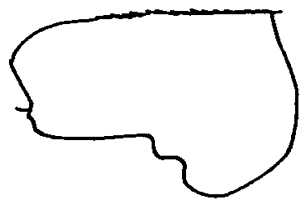

C
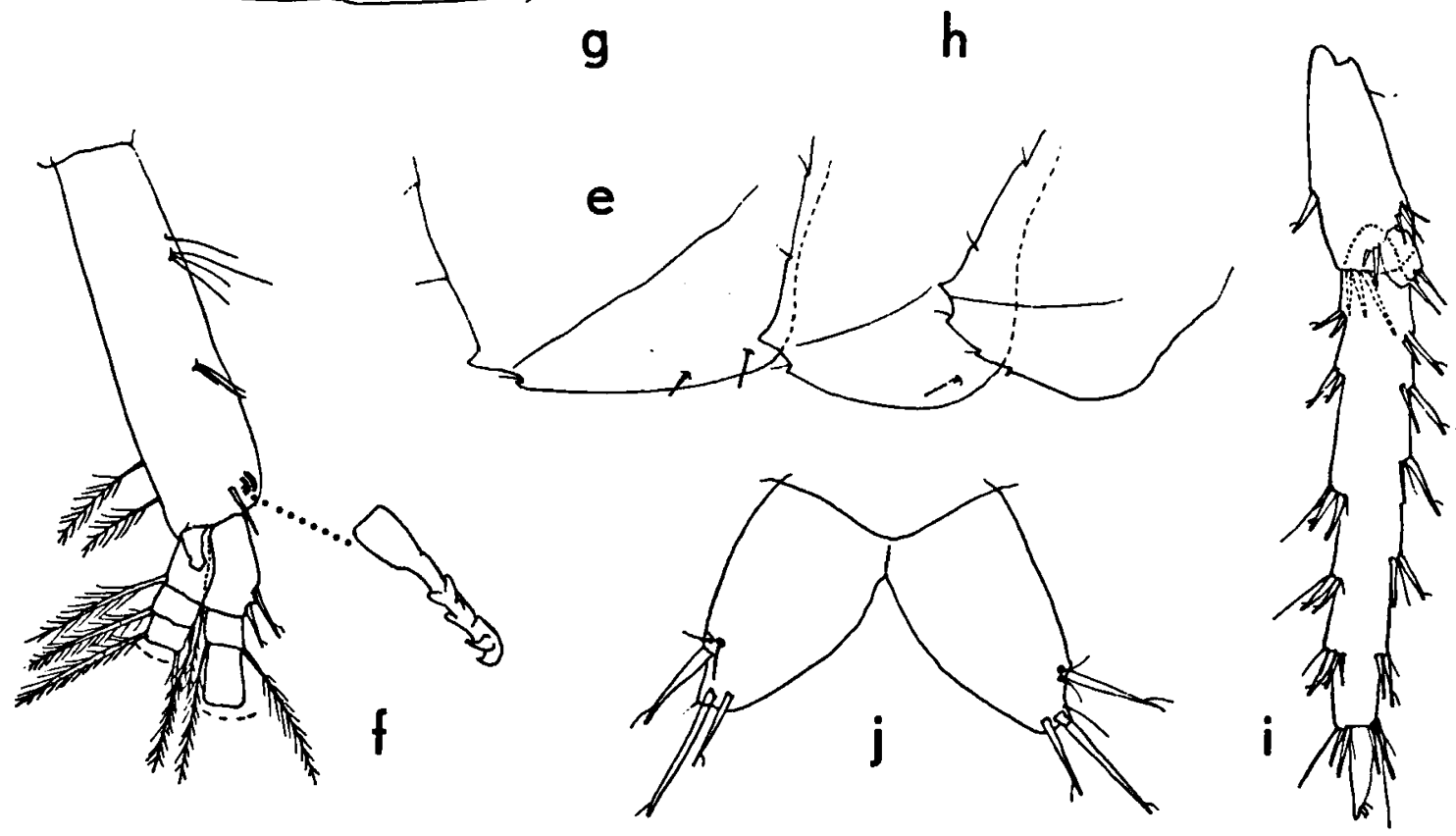

Fig. 15. Caledopisa levis n. gen., n. sp. (c: ९ paratype, remaining figures: $\sigma$ holotype): a, pereiopod 5 (scale 9); b, basal part of pereiopod 6 (9); c, coxal plate 6 (2); d, pereiopod 7 (9); e, epimeral plates 1 to 3 (3); f, basal part of pleopod 3 (2); g, uropod 1 (3); h, uropod 2 (3); i, uropod 3 (3); j, telson (6). Scales on Fig. 5. 
cular spine; both peduncle and rami with 4 to 6 dorsal spines; long interramal spine. Uropod 2 (Fig. 15h) with 4 to 5 dorsal spines on rami. Uropod 3 (Fig. 15i): peduncle more than twice as long as wide; exopodite long, 2-segmented, segment 1 with 5 to 6 groups of spines along margins, intermixed with some setae; endopodite scale-like, with 2 distal spines. Telson (Fig. 15j) almost completely cleft, lobes diverging, with 1 lateral and 2 distal spines.

\section{Acknowledgements}

Collection of specimens from caves in New Caledonia was part of a year-long expedition studying the biology of marine caves in the South Pacific. This research was supported by grants from the National Science Foundation (BSR-8700079) and the National Geographic Society (3412-86). We especially thank Serban Sarbu for his work with collection of specimens. In New Caledonia, Jean François Cherrier, Bertrand Richer de Forges, Pierre Laboute, and M. Boulet provided logistical assistance with this research, while Natalie Baillon and Yolanda Iliffe also helped with cave collections.

\section{References}

Barnard, J.L., 1961. Gammaridean Amphipoda from depths of 400 to $6000 \mathrm{~m}$. Galathea Rep., 5: 23-128.

Barnard, J.L., 1972a. The marine fauna of New Zealand: algaeliving littoral Gammaridea (Crustacea, Amphipoda). New Zealand Dept. scient. industr. Res., Bull. 210: 1-216.

Barnard, J.L., 1972b. Gammaridean Amphipoda of Australia, I. Smithson. Contr. Zool., 103: i-vi, 1-333.

Barnard, J.L. \& C.M. Barnard, 1983. Freshwater Amphipoda of the world, 2 parts: $1-830$ (Hayfield Associates, Mt. Vernon, Virginia).

Bulycheva, A., 1952. Novye vidy bokoplavov (Amphipoda, Gammaridea) iz Japonskogo morja. Trudy zool. Inst., Akad. Nauk SSSR, 12: 195-250.
Chevalier, J.-P., 1975. Loyalty Islands. In: R.W. Fairbridge (ed.), The encyclopedia of world regional geology, part I: Western hemisphere: 342-343 (Dowden, Hutchinson and Ross, Stroudsburg, PA).

Croker, R.A., 1971. A new species of Melita (Amphipoda: Gammaridea) from the Marshall Islands, Micronesia. Pacif. Sci., 25(1): 100-108.

Gamô, S., 1977. A new gammaridean Amphipoda, Melita sexstachya sp. nov. from Sagami Bay, Proc. Jap. Soc. syst. Zool., 13: 65-71.

Karaman, G.S., 1981. Redescription of Melita planaterga Kunkel 1910 from Bermuda islands with revision of genera Melita Leach and Abludomelita n. gen. Poljoprivreda i Sumarstvo, 27(1): 29-50.

Karaman, G.S., 1984. Revision of Eriopisa-complex of genera (Gammaridea). Poljoprivreda i Sumarstvo, 30(4): 39-72.

Karaman, G.S. \& J.L. Barnard, 1979. Revisions in gammaridean Amphipoda (Crustacea), I. Proc. biol. Soc. Wash., 92: 106-165.

Morino, H., 1991. Gammaridean amphipods (Crustacea) from brackish waters of Okinawa Island. Publs. Itako hydrobiol. Stn., 5: 13-26.

Ruffo, S., 1985. Nuovi Anfipodi mesopsammici delle isole Andamane (Crust. Amphipoda). Boll. Mus. civ. Stor. nat. Verona, 10: 485-509.

Tattersall, W.M., 1925. Freshwater Amphipoda from the Andaman Isles. Rec. Ind. Mus., 25(4): 241-247.

Thomas, C., 1987. Grottes de Nouvelle Calédonie: 1-52 (Sophocle, Nouméa).

Yamoto, S., 1987. Four intertidal species of the genus Melita (Crustacea: Amphipoda) from Japanese waters, including [sic] descriptions of two new species. Publs. Seto mar. biol. Lab., 32(4/6): 275-302.

Yamoto, S., 1990. Two new species of the genus Melita (Crustacea: Amphipoda) from shallow waters of the Seto Inland Sea of Japan. Publs. Seto mar. biol. Lab. 34(4/6): 149-165.

Zeidler, W., 1989. A new species of Melita (Crustacea: Amphipoda: Melitidae) from northern New South Wales with a note on the genus Abludomelita Karaman, 1981. Proc. Linn. Soc. N.S.W., 110(4): 327-338.

Received: 20 September 1995 